\title{
A global hotspot for dissolved organic carbon in hypermaritime watersheds of coastal British Columbia
}

\author{
Allison A. Oliver ${ }^{1,2}$, Suzanne E. Tank ${ }^{1,2}$, Ian Giesbrecht ${ }^{2,7}$, Maartje C. Korver ${ }^{2}$, William C. Floyd Ka, $^{3,4,}$ \\ Paul Sanborn $^{5,2}$, Chuck Bulmer ${ }^{6}$, and Ken P. Lertzman ${ }^{7,2}$ \\ ${ }^{1}$ University of Alberta, Department of Biological Sciences, CW 405, Biological Sciences Bldg., University of Alberta, \\ Edmonton, AB, T6G 2E9, Canada \\ ${ }^{2}$ Hakai Institute, Tula Foundation, P.O. Box 309, Heriot Bay, BC, V0P 1H0, Canada \\ ${ }^{3}$ Ministry of Forests, Lands and Natural Resource Operations, 2100 Labieux Rd, Nanaimo, BC, V9T 6E9, Canada \\ ${ }^{4}$ Vancouver Island University, 900 Fifth Street, Nanaimo, BC, V9R 5S5, Canada \\ ${ }^{5}$ Ecosystem Science and Management Program, University of Northern British Columbia, \\ 3333 University Way, Prince George, BC, V2N 4Z9, Canada \\ ${ }^{6}$ BC Ministry of Forests Lands and Natural Resource Operations, 3401 Reservoir Rd, Vernon, BC, V1B 2C7, Canada \\ ${ }^{7}$ School of Resource and Environmental Management, Simon Fraser University, TASC 1 - Room 8405, \\ 8888 University Drive, Burnaby, BC, V5A 1S6, Canada
}

Correspondence to: Allison A. Oliver (aaoliver@ualberta.ca)

Received: 10 January 2017 - Discussion started: 19 January 2017

Revised: 29 June 2017 - Accepted: 10 July 2017 - Published: 15 August 2017

\begin{abstract}
The perhumid region of the coastal temperate rainforest (CTR) of Pacific North America is one of the wettest places on Earth and contains numerous small catchments that discharge freshwater and high concentrations of dissolved organic carbon (DOC) directly to the coastal ocean. However, empirical data on the flux and composition of DOC exported from these watersheds are scarce. We established monitoring stations at the outlets of seven catchments on Calvert and Hecate islands, British Columbia, which represent the rain-dominated hypermaritime region of the perhumid CTR. Over several years, we measured stream discharge, stream water DOC concentration, and stream water dissolved organic-matter (DOM) composition. Discharge and DOC concentrations were used to calculate DOC fluxes and yields, and DOM composition was characterized using absorbance and fluorescence spectroscopy with parallel factor analysis (PARAFAC). The areal estimate of annual DOC yield in water year 2015 was $33.3 \mathrm{Mg} \mathrm{C} \mathrm{km}^{-2} \mathrm{yr}^{-1}$, with individual watersheds ranging from an average of 24.1 to $37.7 \mathrm{Mg} \mathrm{C} \mathrm{km}^{-2} \mathrm{yr}^{-1}$. This represents some of the highest DOC yields to be measured at the coastal margin. We observed seasonality in the quantity and composition of exports, with the majority of DOC export occurring during the
\end{abstract}

extended wet period (September-April). Stream flow from catchments reacted quickly to rain inputs, resulting in rapid export of relatively fresh, highly terrestrial-like DOM. DOC concentration and measures of DOM composition were related to stream discharge and stream temperature and correlated with watershed attributes, including the extent of lakes and wetlands, and the thickness of organic and mineral soil horizons. Our discovery of high DOC yields from these small catchments in the CTR is especially compelling as they deliver relatively fresh, highly terrestrial organic matter directly to the coastal ocean. Hypermaritime landscapes are common on the British Columbia coast, suggesting that this coastal margin may play an important role in the regional processing of carbon and in linking terrestrial carbon to marine ecosystems.

\section{Introduction}

Freshwater aquatic ecosystems process and transport a significant amount of carbon (Cole et al., 2007; Aufdenkampe et al., 2011; Dai et al., 2012). Globally, riverine export is estimated to deliver around $0.9 \mathrm{Pg} \mathrm{C} \mathrm{yr}^{-1}$ from land to the 
coastal ocean (Cole et al., 2007), with typically $>50 \%$ quantified as dissolved organic carbon (DOC) (Meybeck, 1982; Ludwig et al., 1996; Alvarez-Cobelas et al., 2012; Mayorga et al., 2010). Rivers draining coastal watersheds serve as conduits of DOC from terrestrial and freshwater sources to marine environments (Mulholland and Watts, 1982; Bauer et al., 2013; McClelland et al., 2014) and can have important implications for coastal carbon cycling, biogeochemical interactions, ecosystem productivity, and food webs (Hopkinson et al., 1998; Tallis, 2009; Tank et al., 2012; Regnier et al., 2013). In addition, because the transfer of water and organic matter from watersheds to the coastal ocean represents an important pathway for carbon cycling and ecological subsidies between ecosystems, better understanding of these linkages is needed for constraining predictions of ecosystem productivity in response to perturbations such as climate change. In regions where empirical data are currently scarce, quantifying land-to-ocean DOC export is therefore a priority for improving the accuracy of watershed and coastal carbon models (Bauer et al., 2013).

While quantifying DOC flux within and across systems is required for understanding the magnitude of carbon exchange, the composition of DOC (as dissolved organic matter, or DOM) is also important for determining the ecological significance of carbon exported from coastal watersheds. The aquatic DOM pool is a complex mixture that reflects both source material and processing along the watershed terrestrial-aquatic continuum, and as a result it can show significant spatial and temporal variation (Hudson et al., 2007; Graeber et al., 2012; Wallin et al., 2015). Both DOC concentration and DOM composition can serve as indicators of watershed characteristics (Koehler et al., 2009), hydrologic flow paths (Johnson et al., 2011; Helton et al., 2015), and watershed biogeochemical processes (Emili and Price, 2013). DOM composition can also influence its role in downstream processing and ecological function, such as susceptibility to biological (Judd et al., 2006) and physiochemical interactions (Yamashita and Jaffé, 2008).

The coastal temperate rainforests (CTRs) of Pacific North America extend from the Gulf of Alaska through British Columbia to Northern California and span a wide range of precipitation and climate regimes. Within this rainforest region, the "perhumid" zone has cool summers and summer precipitation is common ( $>10 \%$ of annual precipitation) (Alaback, 1996) (Fig. 1). The perhumid CTR extends from southeast Alaska through the outer coast of central British Columbia and contains forests and soils that have accumulated large amounts of organic carbon above and below ground (Leighty et al., 2006; Gorham et al., 2012). Due to high amounts of precipitation and close proximity to the coast, this area represents a potential hotspot for the transport and metabolism of carbon across the land-to-ocean continuum, and quantifying these fluxes is pertinent for understanding global carbon cycling.
Within the large perhumid CTR, there is substantial spatial variation in climate and landscape characteristics that create uncertainty about carbon cycling and pattern. In Alaska, for example, riverine DOC concentrations vary with wetland cover (D'Amore et al., 2015a) and glacial cover (Fellman et al., 2014). Previous studies have shown that streams in southeast Alaska can contain high DOC concentrations (Fellman et al., 2009a; D'Amore et al., 2015a) and produce high DOC yields (D'Amore et al., 2015a, b; Stackpoole et al., 2016), but no known field estimates have been generated for the perhumid CTR of British Columbia, an area of approximately $97824 \mathrm{~km}^{2}$ (adapted from Wolf et al., 1995). Within the perhumid CTR of British Columbia, terrestrial ecologists have defined a large $\left(29935 \mathrm{~km}^{2}\right)$ "hypermaritime" subregion where rainfall dominates over snow, seasonality is moderated by the ocean, and wetlands are extensive (Pojar et al., 1991; area estimated using British Columbia Biogeoclimatic Ecosystem Classification Subzone/Variant mapping Version 10, 31 August 2016, available at https://catalogue.data.gov.bc. ca/dataset/f358a53b-ffde-4830-a325-a5a03ff672c3). Previous work in the hypermaritime CTR showed that DOC concentrations are high in small streams and tend to increase during rain events (Gibson et al., 2000; Fitzgerald et al., 2003; Emili and Price, 2013). Taken together, these conditions should be expected to generate high yields and fluxes of DOC from hypermaritime watersheds to the coastal ocean.

The objectives of this study were to provide the first fieldbased estimates of DOC exports from watersheds in the extensive hypermaritime region of British Columbia's perhumid CTR, to describe the temporal and spatial dynamics of exported DOC concentration and DOM composition, and to identify relationships between DOC concentration, DOM composition, and watershed characteristics.

\section{Methods}

\subsection{Study sites}

Study sites are located on northern Calvert Island and adjacent Hecate Island on the central coast of British Columbia, Canada (lat 51.650, long -128.035; Fig. 1). Average annual precipitation and air temperature at sea level from 1981 to 2010 was $3356 \mathrm{~mm} \mathrm{yr}^{-1}$ and $8.4^{\circ} \mathrm{C}$ (average annual min: $0.9^{\circ} \mathrm{C}$; average annual max: $17.9^{\circ} \mathrm{C}$ ) (available online at http://www.climatewna.com/; Wang et al., 2012), with precipitation dominated by rain and winter snowpack persisting only at higher elevations. Sites are located within the hypermaritime region of the CTR on the outer coast of British Columbia. Soils overlying the granodiorite bedrock (Roddick, 1996) are usually $<1 \mathrm{~m}$ thick and have formed in sandy colluvium and patchy morainal deposits, with limited areas of coarse glacial outwash. Chemical weathering and organic-matter accumulation in the cool, moist climate 


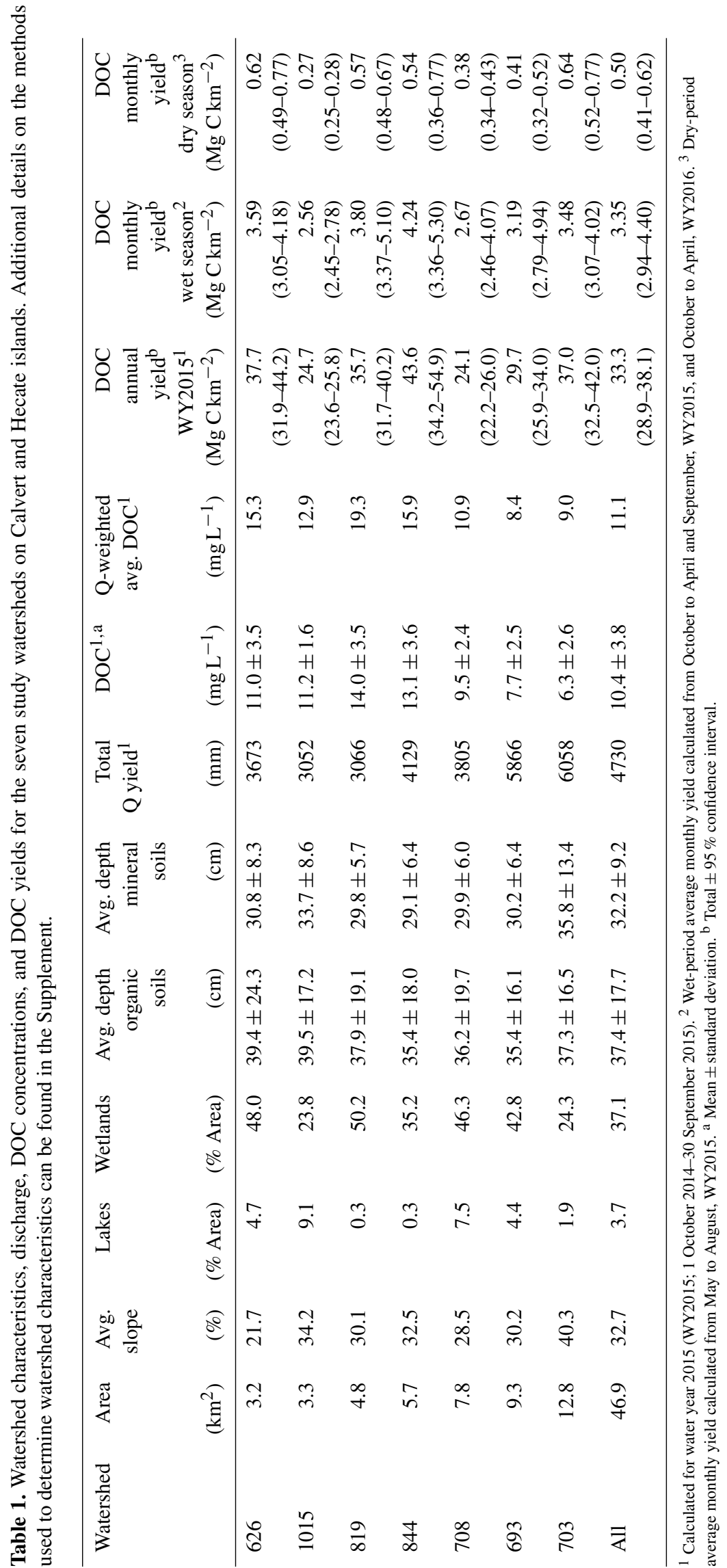




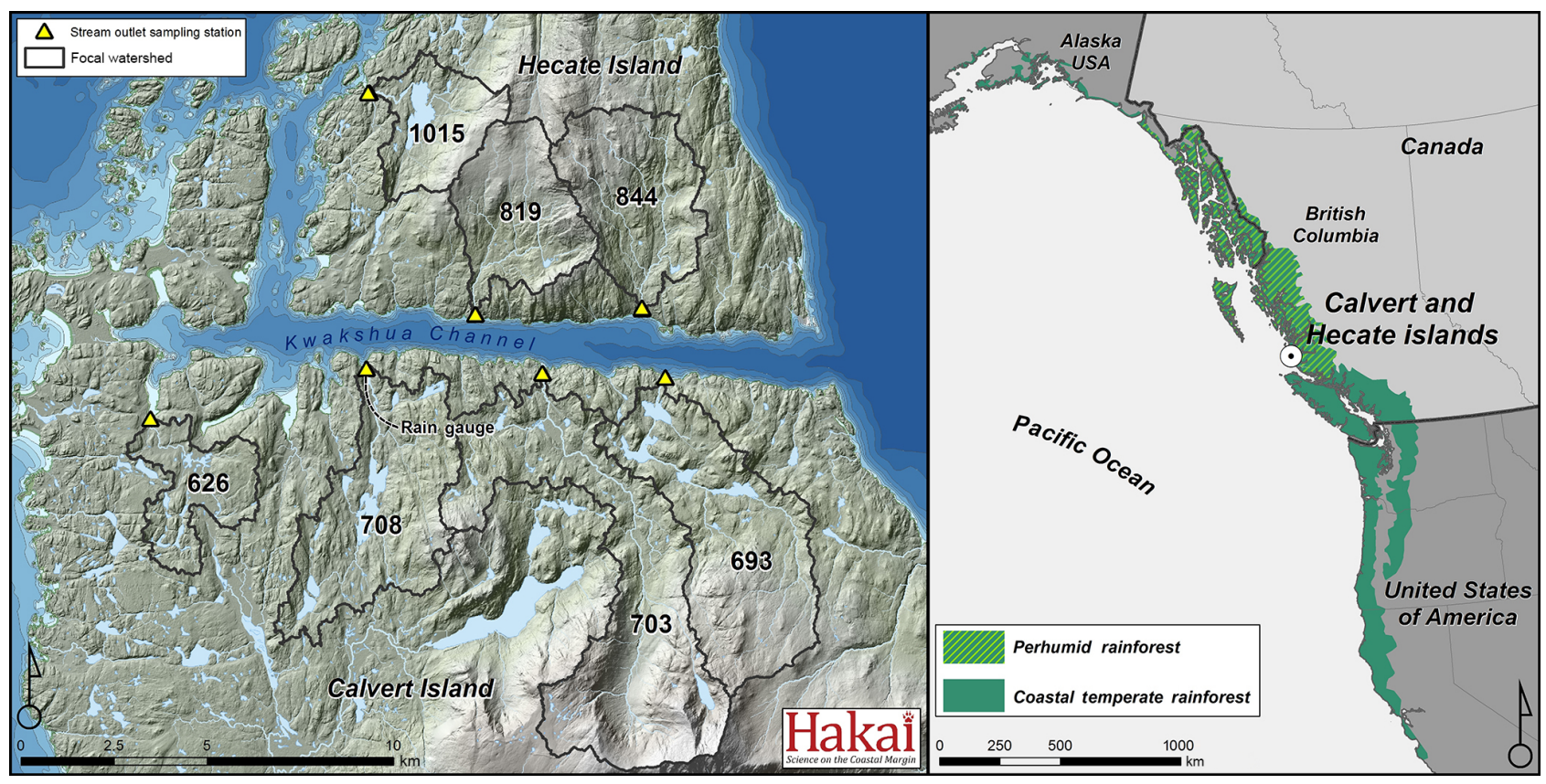

Figure 1. The location of Calvert Island, British Columbia, Canada, within the perhumid region of the coastal temperate rainforest (right) and the study area on Calvert and Hecate islands, including the seven study watersheds, corresponding stream outlet sampling stations, and location of the rain gauge (left). Characteristics of individual watersheds are described in Table 1.

have produced soils dominated by Podzols and Folic Histosols, with Hemists up to $2 \mathrm{~m}$ thick at depressional sites (IUSS Working Group WRB, 2015). The landscape is comprised of a mosaic of ecosystem types, including exposed bedrock, extensive wetlands, "bog forests", and woodlands, with organic-rich soils (Green, 2014; Thompson et al., 2016). Forest stands are generally short with open canopies reflecting the lower productivity of the hypermaritime forests compared to the rest of the perhumid CTR (Banner et al., 2005). Dominant trees are western red cedar, yellow cedar, shore pine, and western hemlock, with composition varying across topographic and edaphic gradients. Widespread understory plants include bryophytes, salal, deer fern, and tufted clubrush. Wetland plants are locally abundant including diverse Sphagnum mosses and sedges. Although the watersheds have no history of mining or industrial logging, archaeological evidence suggests that humans have occupied this landscape for at least 13000 years (McLaren et al., 2014). This occupation has had a local effect on forest productivity near habitation sites (Trant et al., 2016) and on fire regimes (Hoffman et al., 2016). We selected seven watersheds with streams draining directly into the ocean (Fig. 1). These numbered watersheds $(626,693,703,708,819844$, and 1015) range in size (3.2 to $12.8 \mathrm{~km}^{2}$ ) and topography (maximum elevation 160 to $1012 \mathrm{~m})$, are variably affected by lakes $(0.3-9.1 \%$ lake coverage), and - as is characteristic of the perhumid CTR - have a high degree of wetland coverage (24-50\%) (Table 1).

\subsection{Soils and watershed characteristics}

Watersheds and streams were delineated using a $3 \mathrm{~m}$ resolution digital elevation model (DEM) derived from airborne laser scanning (lidar) and flow accumulation analysis using geographic information systems (GISs) to summarize watershed characteristics for each watershed polygon and for all watersheds combined (Gonzalez Arriola et al., 2015; Table 1). Topographic measures were estimated from the DEM, and lake and wetland cover was estimated from the Province of British Columbia terrestrial ecosystem mapping (TEM) (Green, 2014), and soil material thickness was estimated from unpublished digital soil maps (Supplement S1). We recorded the thickness of organic soil material, the thickness of mineral soil material, and total soil depth to bedrock at a total of 353 field sites. Mineral soil horizons have $\leq 17 \%$ organic $\mathrm{C}$, while organic soil horizons have $>17 \%$ organic $\mathrm{C}$, per the Canadian System of Soil Classification (Soil Classification Working Group, 1998). In addition to field-sampled sites, 40 sites with exposed bedrock $(0 \mathrm{~cm}$ soil depth) were located using aerial photography. Soil thicknesses were combined with a suite of topographic, vegetation, and remotesensing (lidar and RapidEye satellite imagery) data for each sampling point and used to train a random forest model (randomForest package in R; Liaw and Wiener, 2002) that was used to predict soil depth values. Soil material thicknesses were then averaged for each watershed (Table 1). For additional details on field site selection and methods used for predictions of soil thickness, see Supplement S1.1. 


\subsection{Sample collection and analysis}

From May 2013 to July 2016, we collected stream water grab samples from each watershed stream outlet every 2-3 weeks $\left(n_{\text {total }}=402\right)$, with less frequent sampling ( monthly) during winter (Fig. 1). All samples were filtered in the field (Millipore Millex-HP Hydrophilic PES $0.45 \mu \mathrm{m}$ ) and kept in the dark, on ice, until analysis. DOC samples were filtered into $60 \mathrm{~mL}$ amber glass bottles and preserved with $7.5 \mathrm{M}$ $\mathrm{H}_{3} \mathrm{PO}_{4}$. Fe samples were filtered into $125 \mathrm{~mL}$ HDPE bottles and preserved with $8 \mathrm{M} \mathrm{HNO}_{3}$. DOC and Fe samples were analyzed at the BC Ministry of the Environment Technical Services Laboratory (Victoria, BC, Canada). DOC concentrations were determined on a total organic carbon (TOC) analyzer (Aurora 1030; OI Analytical) using wet chemical oxidation with persulfate followed by infrared detection of $\mathrm{CO}_{2}$. $\mathrm{Fe}$ concentrations were determined on a dual-view inductively coupled plasma optical emission spectrometry (ICPOES) spectrophotometer (Prodigy; Teledyne Leeman Labs) using a Seaspray pneumatic nebulizer.

In May 2014, we began collecting stream samples for stable isotopic composition of $\delta^{13} \mathrm{C}$ in DOC $\left(\delta^{13} \mathrm{C}-\mathrm{DOC}\right.$; $n=173)$ and the optical characterization of DOM using absorbance spectroscopy $(n=259)$. Beginning in January 2016, we also analyzed samples using fluorescence spectroscopy (see Sect. 2.6). Samples collected for $\delta^{13} \mathrm{C}$ DOC were filtered into $40 \mathrm{~mL}$ EPA glass vials and preserved with $\mathrm{H}_{3} \mathrm{PO}_{4} . \delta{ }^{13} \mathrm{C}$-DOC samples were analyzed at GG Hatch Stable Isotope Laboratory (Ottawa, ON, Canada) using hightemperature combustion (TIC-TOC Combustion Analyser Model 1030; OI Analytical) coupled to a continuous-flow isotope ratio mass spectrometry (Finnigan Mat DeltaPlusXP; Thermo Fischer Scientific) (Lalonde et al., 2014). Samples analyzed for optical characterization using absorbance and fluorescence were filtered into $125 \mathrm{~mL}$ amber HDPE bottles and analyzed at the Hakai Institute (Calvert Island, BC, Canada) within $24 \mathrm{~h}$ of collection.

\subsection{Hydrology: precipitation and stream discharge}

We measured precipitation using a TB4-L tipping bucket rain gauge with a $0.2 \mathrm{~mm}$ resolution (Campbell Scientific Ltd.) located in watershed 708 (elevation: $16 \mathrm{~m}$ a.s.l.). The rain gauge was calibrated twice per year using a field calibration device, model 653 (HYQUEST Solutions Ltd).

We determined continuous stream discharge for each watershed by developing stage discharge rating curves at fixed hydrometric stations situated in close proximity to each stream outlet. Sites were located above tidewater influence and were selected based on favourable conditions (i.e., channel stability and stable hydraulic conditions) for the installation and operation of pressure transducers to measure stream stage. From August 2014 to May 2016 (21 months), we measured stage every $5 \mathrm{~min}$ using a pressure level sensor (OTT PLS-L, OTT Hydromet, Colorado, USA) pressure trans- ducer (0-4 m range SDI-12) connected to a CR1000 (Campbell Scientific, Edmonton, Canada) data logger. Stream discharge was measured over various intervals using either the velocity area method (for flows $<0.5 \mathrm{~m}^{3} \mathrm{~s}^{-1}$; ISO Standard 9196, 1992; ISO Standard 748, 2007) or salt dilution (for flows $>0.5 \mathrm{~m}^{3} \mathrm{~s}^{-1}$; Moore, 2005). Rating curves were developed using the relationship between stream stage height and stream discharge (Supplement S2).

\subsection{DOC flux}

From 1 October 2014 to 30 April 2016, we estimated DOC flux for each watershed using measured DOC concentrations $(n=224)$ and continuous discharge recorded at 15 min intervals. The watersheds in this region respond rapidly to rain inputs and as a result DOC concentrations are highly variable. To address this variability, routine DOC concentration data (as described in Sect. 2.2) were supplemented with additional grab samples $(n=21)$ collected around the peak of the hydrograph during several high-flow events throughout the year. We performed watershed-specific estimates of DOC flux using the rloadest package (Lorenz et al., 2015) in R (version 3.2.5, R Core Team, 2016), which replicates functions developed in the US Geological Survey load-estimator program, LOADEST (Runkel et al., 2004). LOADEST is a multiple-regression adjusted maximum likelihood (ML) estimation model that calibrates a regression between measured constituent values and stream flow across seasons and time and then fits it to combinations of coefficients representing nine predetermined models of constituent flux. To account for potentially small sample size, the best model was selected using the second-order Akaike Information Criterion (AICc) (Akaike, 1981; Hurvich and Tsai, 1989). Input data were log-transformed to avoid bias and centered to reduce multicollinearity. For additional details on model selection, see Supplement Table S3.1.

\subsection{Optical characterization of DOM}

Prior to May 2014, absorbance measures of water samples $(n=99)$ were conducted on a Varian Cary-50 (Varian, Inc.) spectrophotometer at the BC Ministry of the Environment Technical Services Laboratory (Victoria, BC, Canada) to determine specific UV absorption at $254 \mathrm{~nm}\left(\mathrm{SUVA}_{254}\right)$. After May 2014, we conducted optical characterization of DOM by absorbance and fluorescence spectroscopy at the Hakai Institute field station (Calvert Island, BC, Canada) using an Aqualog fluorometer (Horiba Scientific, Edison, New Jersey, USA). Strongly absorbing samples (absorbance units $>0.2$ at $250 \mathrm{~nm}$ ) were diluted prior to analysis to avoid excessive inner filter effects (Lakowicz, 1999). Samples were run in $1 \mathrm{~cm}$ quartz cells and scanned from 220 to $800 \mathrm{~nm}$ at $2 \mathrm{~nm}$ intervals to determine $\mathrm{SUVA}_{254}$ as well as the spectral slope ratio $\left(S_{\mathrm{R}}\right)$. $\mathrm{SUVA}_{254}$ has been shown to positively correlate with increasing molecular aromaticity associated with the 
fulvic acid fraction of DOM (Weishaar et al., 2003), and it is calculated by dividing the decadic absorption coefficient at $254 \mathrm{~nm}$ by DOC concentration $\left(\mathrm{mg} \mathrm{C} \mathrm{L}^{-1}\right)$. To account for potential $\mathrm{Fe}$ interference with absorbance values, we corrected $\mathrm{SUVA}_{254}$ values by $\mathrm{Fe}$ concentration according the method described in Poulin et al. (2014). $S_{\mathrm{R}}$ has been shown to negatively correlate with molecular weight (Helms et al., 2008) and is calculated as the ratio of the spectral slope from 275 to $295 \mathrm{~nm}\left(S_{275-295}\right)$ to the spectral slope from 350 to $400 \mathrm{~nm}\left(S_{350-400}\right)$.

We measured excitation and emission spectra (as excitation emission matrices, EEMs) on samples every three weeks from January to July $2016(n=63)$. Samples were run in $1 \mathrm{~cm}$ quartz cells and scanned from excitation wavelengths of $230-550 \mathrm{~nm}$ at $5 \mathrm{~nm}$ increments and emission wavelengths of $210-620 \mathrm{~nm}$ at $2 \mathrm{~nm}$ increments. The Horiba Aqualog applied the appropriate instrument corrections for excitation and emission, inner filter effects, and Raman signal calibration. We calculated the fluorescence index and freshness index for each EEM. The fluorescence index is often used to indicate DOM source, where higher values are more indicative of microbially derived sources of DOM and lower values indicate more terrestrially derived sources (McKnight et al., 2001), and is calculated as the ratio of emission intensity at 450 to $500 \mathrm{~nm}$, at an excitation of $370 \mathrm{~nm}$. The freshness index is used to indicate the contribution of autochthonous or recently microbial-produced DOM, with higher values suggesting greater autochthony (i.e., microbial inputs), and is calculated as the ratio of emission intensity at $380 \mathrm{~nm}$ to the maximum emission intensity between 420 and $435 \mathrm{~nm}$, at an excitation of $310 \mathrm{~nm}$ (Wilson and Xenopoulos, 2009).

To further characterize features of DOM composition, we performed parallel factor analysis (PARAFAC) using EEM data within the drEEM toolbox for Matlab (Mathworks, MA, USA) (Murphy et al., 2013). PARAFAC is a statistical technique used to decompose the complex mixture of the fluorescing DOM pool into quantifiable, individual components (Stedmon et al., 2003). We detected a total of six unique components and validated the model using core consistency and split-half analysis (Murphy et al., 2013; Stedmon and Bro, 2008). Components with similar spectra from previous studies were identified using the online fluorescence repository, OpenFluor (Murphy et al., 2014), and additional components with similar peaks were identified through literature review. Since the actual chemical structure of fluorophores is unknown, we used the concentration of each fluorophore as maximum fluorescence of excitation and emission in Raman units $\left(F_{\max }\right)$ to derive the percent contribution of each fluorophore component to total fluorescence. Relationships between PARAFAC components were also evaluated using Pearson correlation coefficients in the $\mathrm{R}$ package Hmisc (Harrell et al., 2016).

\subsection{Evaluating relationships in DOC concentration and DOM composition with stream discharge and temperature}

We used linear mixed-effects (LME) models to assess the relationship between DOC concentration or DOM composition $\left({ }^{13} \mathrm{C}-\mathrm{DOC}, S_{\mathrm{R}}, \mathrm{SUVA}_{254}\right.$, fluorescence index, freshness index, PARAFAC components), stream discharge, and stream temperature. Analysis was performed in R using the nlme package (Pinheiro et al., 2016). Watershed was included as a random intercept to account for repeat measures on each watershed. For some parameters, a random slope of either discharge or temperature was also included based on data assessment and model selection. Model selection was performed using AIC to compare models fit using ML (Burnham and Anderson, 2002; Symonds and Moussalli, 2010). The final model was fit using restricted maximum likelihood (REML). Marginal $R^{2}$, which represents an approximation of the proportion of the variance explained by the fixed factors alone, and conditional $R^{2}$, which represents an approximation of the proportion of the variance explained by both the fixed and random factors, were calculated based on the methods described in Nakagawa and Schielzeth (2013) and Johnson (2014).

\subsection{Redundancy analysis: relationships between DOC concentration, DOM composition, and watershed characteristics}

We evaluated relationships between stream water DOC and watershed characteristics by relating DOC concentration and measures of DOM composition to catchment attributes using redundancy analysis (RDA; type 2 scaling) in the package rdaTest (Legendre and Durand, 2014) in R (version 3.2.2, $\mathrm{R}$ Core Team, 2015). To maximize the amount of information available, we performed RDA analysis on samples collected from January to July 2016 and therefore included all parameters of optical characterization (i.e., all PARAFAC components and spectral indices). We assessed the collinearity of DOM compositional variables using a variance inflation factor (VIF) criteria of $>10$, which resulted in the removal of PARAFAC components $\mathrm{C} 2, \mathrm{C} 3$, and $\mathrm{C} 5$ prior to RDA analysis. Catchment attributes for each watershed included average slope, percent area of lakes, percent area of wetlands, average depth of mineral soil, and average depth of organic soil. Relationships between variables were linear, so no transformations were necessary and variables were standardized prior to analysis. To account for repeat monthly measures per watershed and potential temporal correlation associated with monthly sampling, we included sample month as a covariable ("partial-RDA"). To test whether the RDA axes significantly explained variation in the dataset, we compared permutations of residuals using ANOVA (9999 iterations; test.axes function of rdaTest). 


\section{Results}

\subsection{Hydrology}

We present work for water year 2015 (WY2015; 1 October 2014-30 September 2015) and water year 2016 (WY2016; 1 October 2015-30 September 2016). Annual precipitation for both water years was lower than historical mean annual precipitation (WY2015: $2661 \mathrm{~mm}$; WY2016: $2587 \mathrm{~mm}$ ). It is worth noting that mean annual precipitation at our rain gauge location ( $2890 \mathrm{~mm} \mathrm{yr}^{-1}$; elevation: $16 \mathrm{~m}$ ) is substantially lower than the average amount received at higher elevations, which from 1981 to 2010 was approximately $5027 \mathrm{~mm} \mathrm{yr}^{-1}$ at an elevation of $1000 \mathrm{~m}$ within our study area. This area receives a very high amount of annual rainfall but also experiences seasonal variation, with an extended wet period from fall through spring and a much shorter, typically drier period during summer. In WY2015 and WY2016, 86-88\% of the annual precipitation on Calvert Island occurred during the 8 months of wetter and cooler weather between September and April ( $~ 75 \%$ of the year), designated the "wet period" (WY2015 wet: $2388 \mathrm{~mm}$, average air temp: $7.97^{\circ} \mathrm{C}$; WY2016 wet: $2235 \mathrm{~mm}$, average air temp: $7.38^{\circ} \mathrm{C}$ ). The remaining annual precipitation occurred during the drier and warmer summer months of MayAugust, designated the "dry period" (WY2015 dry: $314 \mathrm{~mm}$, average air temp: $13.4^{\circ} \mathrm{C}$; WY2016 dry: $352 \mathrm{~mm}$, average air temp: $13.1^{\circ} \mathrm{C}$ ). Overall, although WY2015 was slightly wetter than WY2016, the two years were comparable in relative precipitation during the wet versus dry periods.

Stream discharge $(Q)$ responded rapidly to rain events and as a result, closely tracked patterns in total precipitation (Fig. 2). Total $Q$ for all watersheds was on average $22 \%$ greater for the wet period of WY2015 (total $Q: 223.02 \times 10^{6}$; range: $\left.5.13 \times 10^{6}-111.51 \times 10^{6} \mathrm{~m}^{3}\right)$ compared to the wet period of WY2016 (total $Q: 182.89 \times 10^{6}$; range: $\left.4.17 \times 10^{6}-91.45 \times 10^{6} \mathrm{~m}^{3}\right)$. Stream discharge and stream temperature were significantly different for wet versus dry periods (Mann-Whitney tests, $p<0.0001$ ).

\subsection{Temporal and spatial patterns in DOC concentration, yield, and flux}

Stream waters were high in DOC concentration relative to the global average for freshwater discharged directly to the ocean (average DOC for Calvert and Hecate islands: $10.4 \mathrm{mg} \mathrm{L}^{-1}$, SD: 3.8 ; average global DOC: $\sim 6 \mathrm{mg} \mathrm{L}^{-1}$ ) (Meybeck, 1982; Harrison et al., 2005) (Table 1; Fig. 3). $Q$-weighted average DOC concentrations were higher than average measured DOC concentrations $\left(11.1 \mathrm{mg} \mathrm{L}^{-1}\right.$, Table 1), and also resulted in slightly different ranking of the watersheds for highest to lowest DOC concentration. Within watersheds, $Q$-weighted DOC concentrations ranged from a low of $8.4 \mathrm{mg} \mathrm{L}^{-1}$ (watershed 693) to a high of $19.3 \mathrm{mg} \mathrm{L}^{-1}$ (watershed 819), and concentrations were sig-
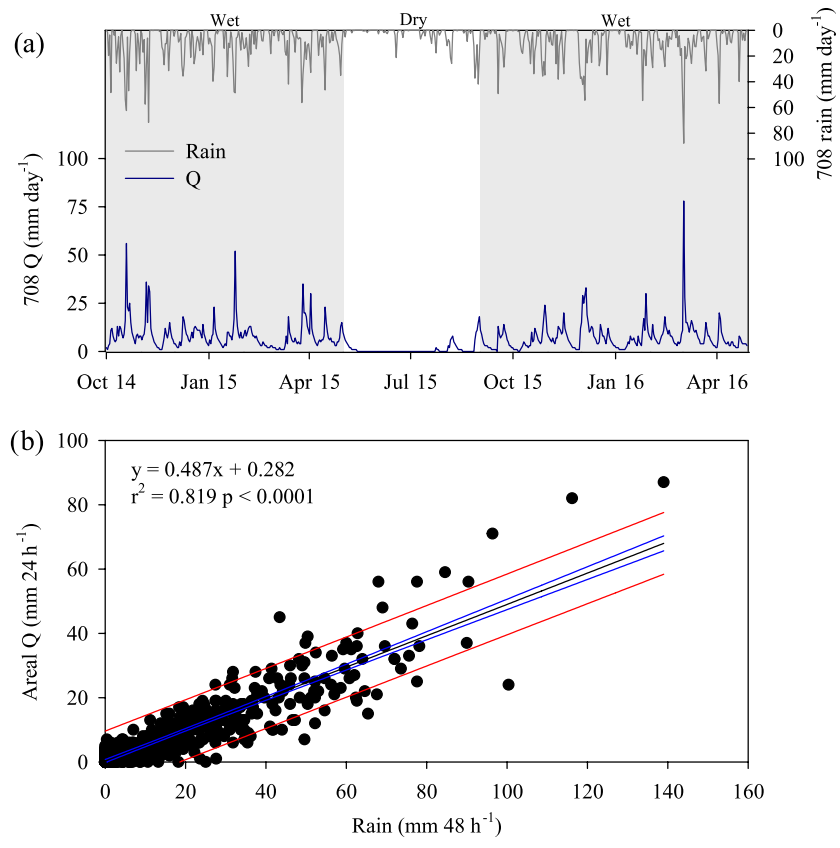

Figure 2. Hydrological patterns typical of watersheds located in the study area. (a) The hydrograph and precipitation record from Watershed 708 for the study period of 1 October 2015-30 April 2016. Grey shading indicates the wet period (1 September-30 April) and the unshaded region indicates the dry period (1 May-30 August). (b) Correlation of daily $(24 \mathrm{~h})$ areal runoff (discharge of all watersheds combined) to $48 \mathrm{~h}$ total rainfall recorded at watershed 708 . For the period of study, comparisons of daily runoff to $48 \mathrm{~h}$ rainfall (runoff : rainfall mean: $0.92 ; \mathrm{SD} \pm 0.27$ ) indicated rapid discharge response to rainfall.

nificantly different between watersheds (Kruskal-Wallis test, $p<0.0001$ ). Seasonal variability tended to be higher in watersheds where DOC concentration was also high (watersheds 626, 819, and 844) and lower in watersheds with greater lake area (watersheds 1015 and 708) (Table 1; box plots, Fig. 3). On an annual basis, DOC concentrations generally decreased through the wet period and increased through the dry period, and concentrations were significantly lower during the wet period compared to the dry period (MannWhitney test, $p=0.0123$ ). Results of our LME model (Table S6.1) indicate that DOC concentration was positively related to both discharge $(b=0.613, p<0.001)$ and temperature $(b=0.162, p=0.011)$ (model conditional $R^{2}=0.57$, marginal $R^{2}=0.09$ ).

Annual and monthly DOC yields are presented in Table 1. For the total period of available $Q$ (1 October 2014-30 April 2016; 19 months), areal (all watersheds) DOC yield was $52.3 \mathrm{Mg} \mathrm{C} \mathrm{km}^{-2}$ (95\% CI: 45.7 to $68.2 \mathrm{Mg} \mathrm{C} \mathrm{km}^{-2}$ ) and individual watershed yields ranged from 24.1 to $43.6 \mathrm{Mg} \mathrm{C} \mathrm{km}^{-2}$. For WY2015, areal annual DOC yield was $33.3 \mathrm{Mg} \mathrm{C} \mathrm{km}^{-2} \mathrm{yr}^{-1}$ (95\% CI: 28.9 to $38.1 \mathrm{Mg} \mathrm{C} \mathrm{km}^{-2} \mathrm{yr}^{-1}$ ). Total monthly rainfall was strongly 


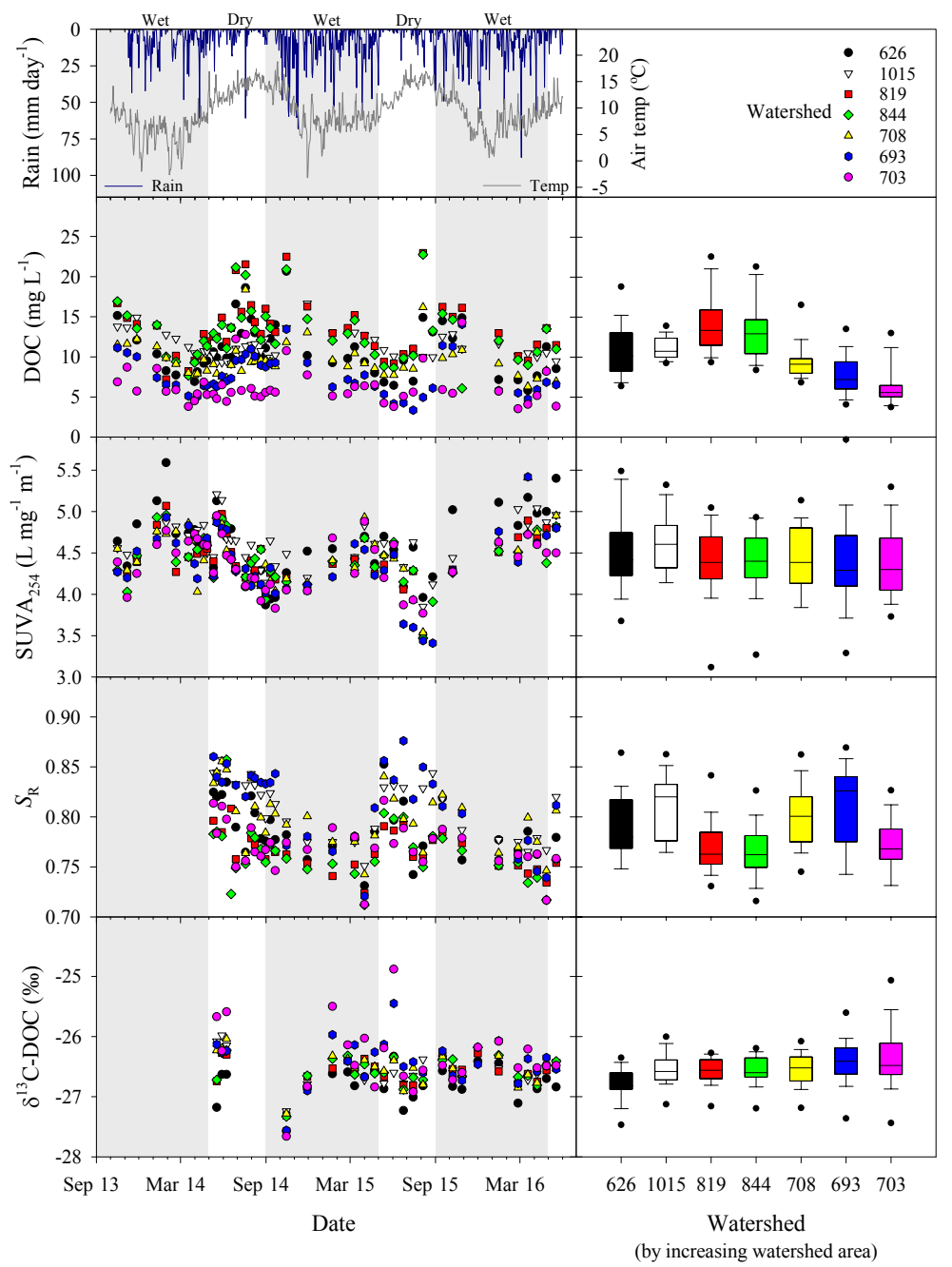

Figure 3. Seasonal (timelines, by date) and spatial (box plots, by watershed) patterns in DOC concentration and DOM composition for stream water collected at the outlets of the seven study watersheds on Calvert and Hecate islands. Boxes represent the 25th and 75th percentile, while whiskers represent the 5th and 95th percentile. Daily precipitation and annual temperature are shown in the top left panel. Grey shading indicates the wet period (1 September-30 April) and the unshaded region indicates the dry period of each water year.

correlated with monthly DOC yield (Fig. 4), and average monthly yield for the wet period $\left(3.35 \mathrm{Mg} \mathrm{C} \mathrm{km}^{-2}\right.$ month $^{-1}$; $95 \%$ CI: 2.94 to $4.40 \mathrm{Mg} \mathrm{C} \mathrm{km}{ }^{-2}$ month $^{-1}$ ) was significantly greater than average monthly yield during the dry period $\left(0.50 \mathrm{Mg} \mathrm{C} \mathrm{km}\right.$ month $^{-1} ; 95 \%$ CI: 0.41 to $0.62 \mathrm{Mg} \mathrm{C} \mathrm{km}{ }^{-2}$ month $^{-1}$ ) (Mann-Whitney test, $p<0.0001)$.

Across our study watersheds, DOC flux generally increased with increasing watershed area (Fig. 5). In WY2015, total DOC flux for all watersheds included in our study was $1562 \mathrm{Mg} \mathrm{C}$ (95\% CI: 1355 to $1787 \mathrm{Mg} \mathrm{C}$ ), and individual watershed flux ranged from ranged from 82 to $276 \mathrm{Mg} \mathrm{C}$. DOC flux was significantly different in wet versus dry periods (Mann-Whitney test, $p<0.0001$ ). Overall, $94 \%$ of the export in WY2015 occurred during the wet period, and ex- port for the wet period of WY2015 was lower than export for the wet period of WY2016 (Fig. 5).

\subsection{Temporal and spatial patterns in DOM composition}

The stable isotopic composition of dissolved organic carbon $\left({ }^{13} \mathrm{C}\right.$-DOC) was relatively tightly constrained over space and time (average $\delta^{13} \mathrm{C}$-DOC: $-26.53 \%$, SD: 0.36; range: -27.67 to $-24.89 \%$ o). Values of $S_{\mathrm{R}}$ were low compared to the range typically observed in surface waters (average $S_{\mathrm{R}}=0.78$, SD: 0.04; range: 0.71 to 0.89 ), and Fe-corrected SUVA $_{254}$ values were at the high end of the range compared to most surface waters (average $\mathrm{SUVA}_{254}$ for Calvert and Hecate islands: $4.42 \mathrm{~L} \mathrm{mg}^{-1} \mathrm{~m}^{-1}$, SD: 0.46 ; range of SUVA $_{254}$ in surface waters: 1.0 to $5.0 \mathrm{~L} \mathrm{mg}^{-1} \mathrm{~m}^{-1}$ ) (Spencer et al., 2012). Values for both the fluorescence index (average fluorescence index: 1.36 , SD: 0.04 ; range: 1.30 to 


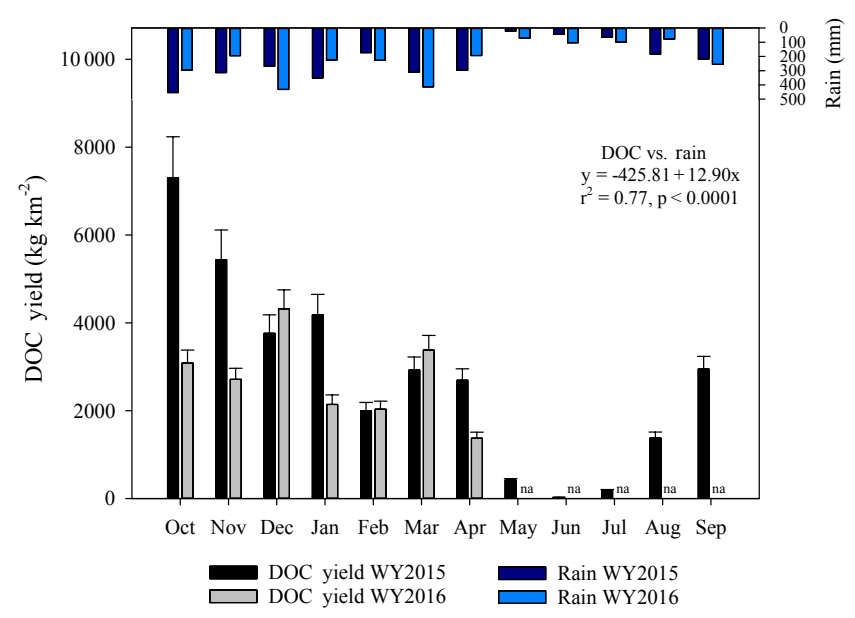

Figure 4. Monthly areal DOC yields and precipitation for water year 2015 (WY2015) and the wet period (1 October-30 April) of water year 2016 (WY2016). Error bars represent standard error. Total rain and DOC yield were significantly correlated $\left(r^{2}=\right.$ 0.77 ), and months of higher rain produced higher DOC yields. In WY2015, the majority of DOC export ( $~ 94 \%$ of annual flux) occurred during the wet period ( $\sim 88 \%$ of annual precipitation).

1.44) and freshness index (average freshness index: 0.46, SD: 0.02 ; range: 0.41 to 0.49 ) were relatively low compared to the typical range found in surface waters (Fellman et al., 2010; Hansen et al., 2016). Differences between watersheds were observed for $\delta^{13} \mathrm{C}$-DOC (Kruskal-Wallis test, $p=0.0043), S_{\mathrm{R}}$ (Kruskal-Wallis test, $\left.p=0.0001\right)$, fluorescence index (Kruskal-Wallis test, $p=0.0030$ ), and freshness index (Kruskal-Wallis test, $p=0.0099$ ), but watersheds did not differ in $\mathrm{SUVA}_{254}$ (Kruskal-Wallis test, $p=0.4837$ ).

We observed seasonal variability in $\delta^{13} \mathrm{C}$-DOC throughout the period of sampling (Fig. 3 and our LME model (Table S6.1) indicate that $\delta^{13} \mathrm{C}$-DOC declined with increasing discharge $(b=-0.049, p=0.014)$ and stream temperature $(b=-0.024, p<0.001)$ (model conditional $R^{2}=0.35$, marginal $R^{2}=0.10$ ). In contrast, although $\mathrm{SUVA}_{254}$ appeared to exhibit a general seasonal trend of values increasing over the wet period and decreasing over the dry period, $\mathrm{SUVA}_{254}$ was not significantly related to either discharge or stream temperature in the LME model results. $S_{\mathrm{R}}$ also appeared to fluctuate seasonally, with lower values during the wet season and higher values during the dry season. $S_{\mathrm{R}}$ was negatively related to discharge $(b=-0.026$; $p<0.001)$ and positively related to the interaction between discharge and stream temperature $(b=0.0015 ; p<0.001)$ (model conditional $R^{2}=0.62$; marginal $R^{2}=0.28$ ). The freshness index was negatively related to stream temperature $(b=-0.003 ; p=0.008)$ (model conditional $R^{2}=0.59$; marginal $R^{2}=0.23$ ), while the fluorescence index was not significantly related to either discharge or stream temperature.

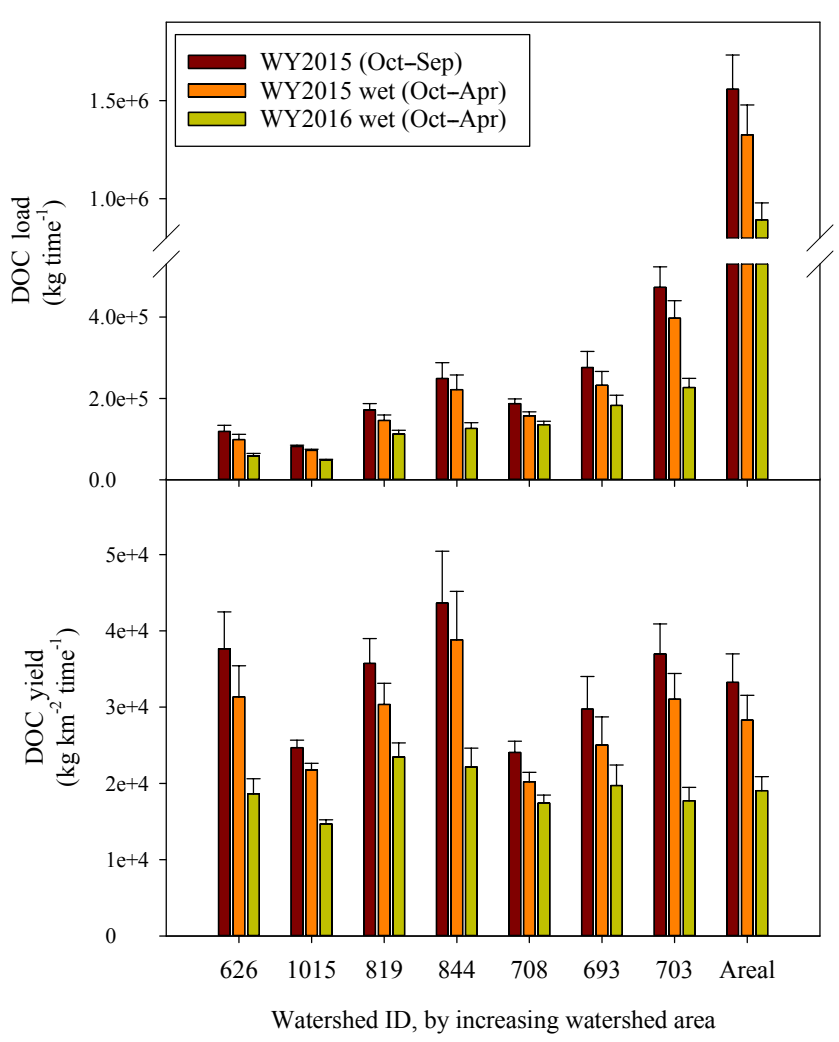

Figure 5. DOC fluxes and yields for the seven study watersheds and the total area of study ("areal", all watersheds combined) on Calvert and Hecate islands for water year 2015 (WY2015; 1 October30 September), and 1 October-30 April of the wet period for water year 2015 (WY2015 wet) and water year 2016 (WY2016 wet). Because DOC yields were only available for September in WY2015, this month was excluded from the wet-period totals in order to make similar comparisons between years. Error bars represent standard error.

\subsection{PARAFAC characterization of DOM}

Six fluorescence components were identified through PARAFAC ("C1" through "C6") (Table 2). Additional details on PARAFAC model results are provided in Supplement Table S4.1 and Figs. S4.2 and S4.3. Of the six components, four were found to have close spectral matches in the OpenFluor database (C1, C3, C5, C6; minimum similarity score $>0.95)$, while the remaining two $(\mathrm{C} 2$ and $\mathrm{C} 4)$ were found to have similar peaks represented in the literature. The first four components $(\mathrm{C} 1$ through $\mathrm{C} 4)$ are described as terrestrially derived, whereas components C5 and C6 are described as autochthonous or microbially derived (Table 2). In general, the rank order of each component's percent contribution to total fluorescence was maintained over time, with $\mathrm{C} 1$ comprising the majority of total fluorescence across all watersheds (Fig. 6).

Across watersheds, components fluctuated synchronously over time and variation between watersheds was relatively 


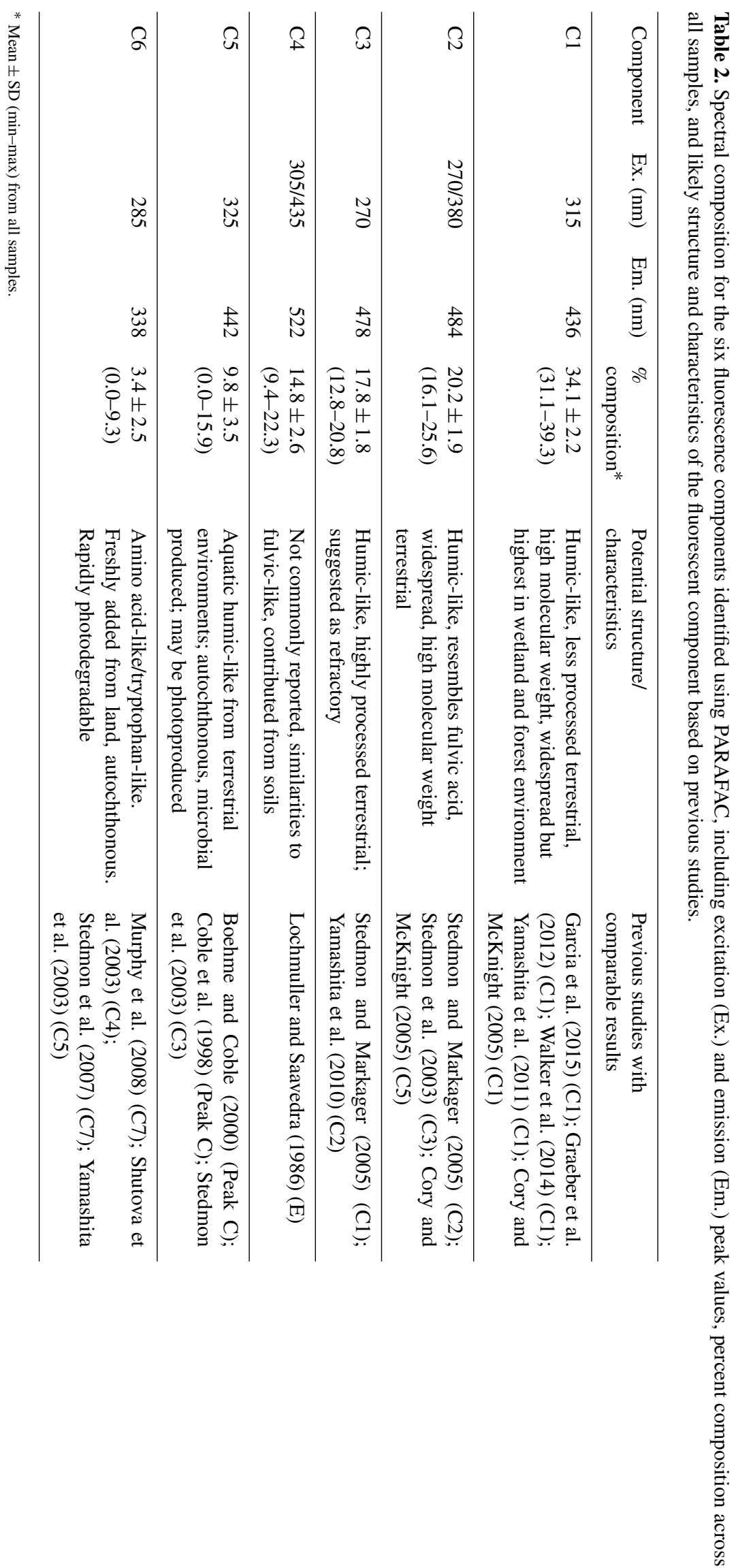




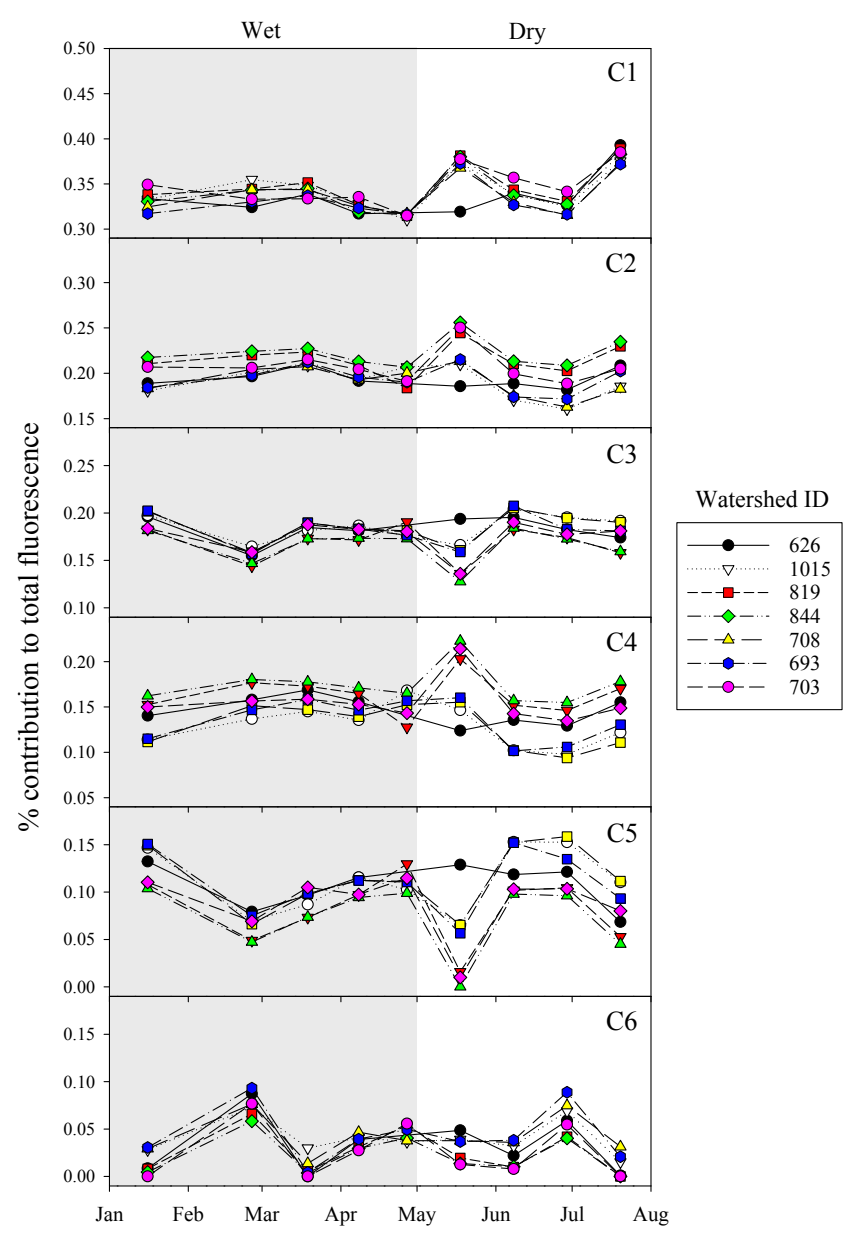

Figure 6. Percent contribution of the six components identified in parallel factor analysis (PARAFAC) for samples collected every three weeks from January-July 2016 from the seven study watersheds on Calvert and Hecate islands. The grey shading indicates the wet period and the unshaded region indicates the dry period. Note that while the $y$ axis for each panel has a range of $20 \%$, the max and min for each $y$ axis varies by panel.

low, although slightly more variation between watersheds was observed during the beginning of the dry period relative to other times of the year (Fig. 6). The percent contributions of components $\mathrm{C} 1, \mathrm{C} 3, \mathrm{C} 5$, and $\mathrm{C} 6$ to total fluorescence were not significantly different across watersheds (for all components Kruskal-Wallis test, $p>0.05$ ); however, the percent composition of both $\mathrm{C} 2$ and $\mathrm{C} 4$ was different (KruskalWallis test, $p=0.0306$ and $p=0.0307$, respectively) and higher for watersheds 819 and 844 relative to the other watersheds (Fig. S4.4).

PARAFAC components exhibited significant relationships with stream discharge and stream temperature, although predicted changes (beta, or $b$ ) in fluorescence components with discharge and/or stream temperature were small (Supplement Table S6.2). C3 increased with discharge $(b=0.006, p=0.003)$, whereas $\mathrm{C} 2, \mathrm{C} 4$, and $\mathrm{C} 5$ decreased with discharge (C2: $b=-0.005, p=0.022 ; \mathrm{C} 4: b=-0.008$, $p=0.002$; C5: $b=-0.008, p=0.002) . \mathrm{C} 1, \mathrm{C} 4$, and $\mathrm{C} 6$ increased with temperature $(\mathrm{C} 1: b=0.001, p=0.050 ; \mathrm{C} 4$ : $b=0.003, p<0.001$; C6: $b=0.005, p=0.005$ ), while both $\mathrm{C} 3$ and C5 decreased with temperature (C3: $b=-0.003$, $p=0.003$; C $5: b=-0.003, p=0.027)$. Conditional $R^{2}$ values for the models ranged from 0.28 to 0.69 , while marginal $R^{2}$ ranged from 0.20 to 0.46 . Overall, greater changes in component contribution to total fluorescence were observed with changes in discharge relative to changes in stream temperature.

\subsection{Relationships between watershed characteristics, DOC concentrations, and DOM composition}

Results of the partial RDA (type 2 scaling) were significant in explaining variability in DOM concentration and composition (semi-partial $R^{2}=0.33, F=7.90, p<0.0001$ ) (Fig. 7). Axes 1 through 3 were statistically significant at $p<0.001$, and the relative contribution of each axis to the total explained variance was 47,30 , and $22 \%$, respectively. Additional details on the RDA test are provided in Figs. S5.1-S5.2 and Tables S5.3-S5.5. Axis 1 described a gradient of watershed coverage by water-inundated ecosystem types, ranging from more wetland coverage to more lake coverage. Total lake coverage (area) and mean mineral soil material thickness showed a strong positive contribution, and wetland coverage (area) showed a strong negative contribution to this axis. The freshness index, the fluorescence index, $S_{\mathrm{R}}$, and the fluorescence component C6 were positively correlated with Axis 1, while component $\mathrm{C} 4$ showed a clear negative correlation. Axis 2 described a subtler gradient of soil material thickness ranging from greater mean organic soil material thickness to greater mean mineral soil material thickness. DOC concentration, $\delta^{13} \mathrm{C}$-DOC, $\mathrm{SUVA}_{254}$, and fluorescence component $\mathrm{C} 1$ all showed a strong, positive correlation with Axis 2. Axis 3 described a gradient of watershed steepness, from lower gradient slopes with more wetland area and thicker organic soil material to steeper slopes with less developed organic horizons. Average slope contributed negatively to Axis 3 (see Table S5.5), followed by positive contributions from both wetland area and the thickness of organic soil material. $\delta^{13} \mathrm{C}$-DOC showed the most positive correlation with Axis 3, whereas fluorescence components $\mathrm{C} 1$ and $\mathrm{C} 4$ showed the most negative.

\section{Discussion}

\subsection{DOC export from small catchments to the coastal ocean}

In comparison to global models of DOC export (Mayorga et al., 2010) and DOC exports quantified for southeastern Alaska (D'Amore et al., 2015a, 2016; Stackpoole et al., 2017), our estimates of freshwater DOC yield from Calvert 


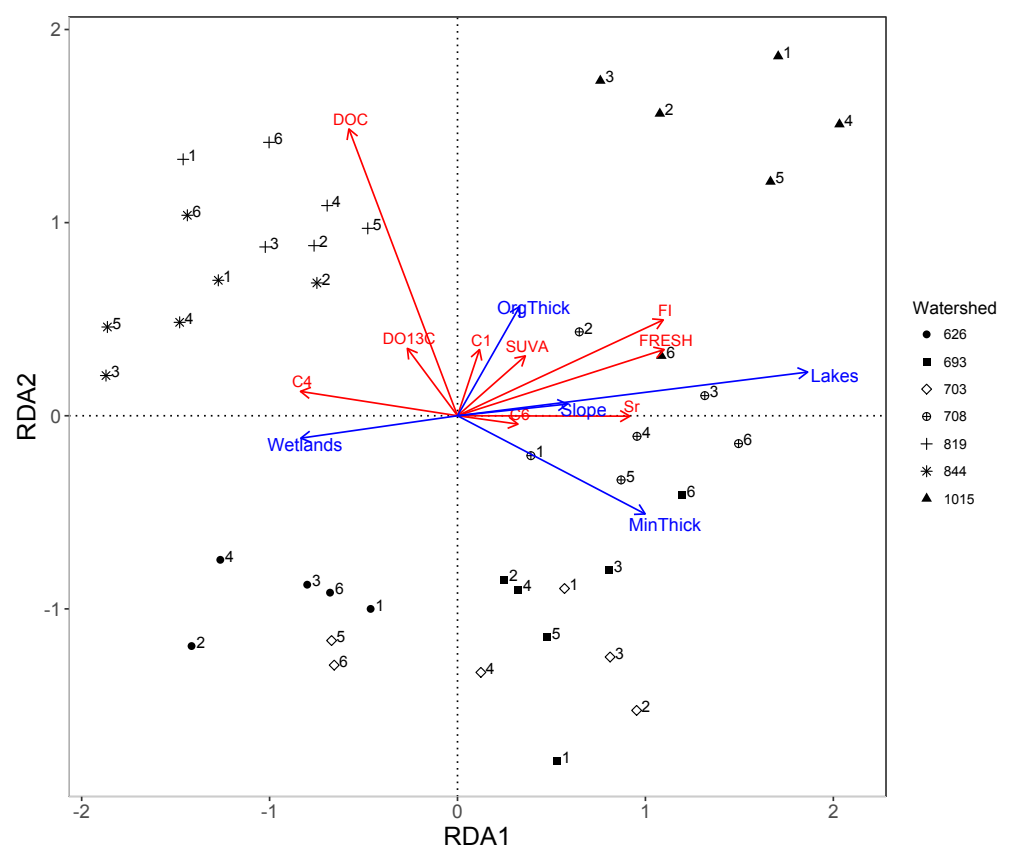

Figure 7. Results from the partial redundancy analysis (RDA; type 2 scaling) of DOC concentration and DOM composition versus watershed characteristics. Angles between vectors represent correlation; i.e., smaller angles indicate higher correlation. Symbols represent different watersheds, and numbers on symbols represent the sample month in 2016: 1 - January; 2 - February; 3 - March; 4 - early April; 5 - late April; and 6-May.

and Hecate island watersheds are in the upper range predicted for the perhumid rainforest region. When compared to watersheds of similar size, DOC yields from Calvert and Hecate island watersheds are some of the highest observed (see reviews in Hope et al., 1994; Alvarez-Cobelas et al., 2012), including DOC yields from many tropical rivers, despite the fact that tropical rivers have been shown to export very high DOC (e.g., Autuna River, Venezuela, DOC yield: $56946 \mathrm{~kg} \mathrm{C} \mathrm{km}^{-2} \mathrm{yr}^{-1}$; Castillo et al., 2004) and are often regarded as having disproportionately high carbon export compared to temperate and Arctic rivers (Aitkenhead and McDowell, 2000; Borges et al., 2015). Our estimates of DOC yield are comparable to, or higher than, previous estimates from high-latitude catchments of similar size that receive high amounts of precipitation and contain extensive organic soils and wetlands (e.g., Naiman, 1982 (DOC yield: $48380 \mathrm{~kg} \mathrm{C} \mathrm{km}^{-2} \mathrm{yr}^{-1}$ ); Brooks et al., 1999 (DOC yield: $20300 \mathrm{~kg} \mathrm{C} \mathrm{km}^{-2} \mathrm{yr}^{-1}$ ); Ågren et al., 2007 (DOC yield: $32043 \mathrm{~kg} \mathrm{C} \mathrm{km}^{-2} \mathrm{yr}^{-1}$ )). However, many of these catchments represent low- (first- or second-) order headwater streams that drain to higher-order stream reaches, rather than directly to the ocean. Although headwater streams have been shown to export up to $90 \%$ of the total annual carbon in stream systems (Leach et al., 2016), significant processing and loss typically occurs during downstream transit (Battin et al., 2008).

Over much of the incised outer coast of the CTR, small rainfall-dominated catchments contribute high amounts of freshwater runoff to the coastal ocean (Royer, 1982; Morrison et al., 2012; Carmack et al., 2015). Small mountainous watersheds that discharge directly to the ocean can exhibit disproportionately high fluxes of carbon relative to watershed size and in aggregate may deliver more than $50 \%$ of total carbon flux from terrestrial systems to the ocean (Milliman and Syvitski, 1992; Masiello and Druffel, 2001). Extrapolating our estimate of annual DOC yield from Calvert and Hecate island watersheds to the entire hypermaritime subregion of British Columbia's CTR $\left(29935 \mathrm{~km}^{2}\right)$ generates an estimated annual DOC flux of $0.997 \mathrm{Tg} \mathrm{C} \mathrm{yr}^{-1}(0.721$ to $1.305 \mathrm{Tg} \mathrm{Cyr}^{-1}$ for our lowest to highest yielding watersheds, respectively), with the caveat that this estimate is rudimentary and does not account for spatial heterogeneity in controlling factors such as wetland extent, topography, and watershed size. Regional comparisons estimate that Southeast Alaska $\left(104000 \mathrm{~km}^{2}\right)$, at the northern range of the CTR, exports approximately $1.25 \mathrm{Tg} \mathrm{C} \mathrm{yr}^{-1}$ (Stackpoole et al., 2016), while south of the perhumid CTR, the wet northwestern United States and its associated coastal temperate rainforests export less than $0.153 \mathrm{Tg} \mathrm{C} \mathrm{yr}^{-1}$ as DOC (reported as TOC; Butman et al., 2016). This suggests that the hypermaritime coast of British Columbia plays an important role in the export of DOC from coastal temperate rainforest ecosystems of western North America, in a region that is already expected to contribute high quantities of DOC to the coastal ocean. 


\subsection{DOM composition}

The composition of stream water DOM exported from Calvert and Hecate island watersheds is mainly terrestrial, indicating that the production and overall supply of terrestrial material is sufficient to exceed microbial demand, and thus a relatively abundant supply of terrestrial DOM is available for export. Values for $\delta^{13} \mathrm{C}$-DOC suggest that terrestrial carbon sources from $\mathrm{C} 3$ plants and soils were the dominant input to catchment stream water DOM (Finlay and Kendall, 2007). Measures of $S_{\mathrm{R}}$ and $\mathrm{SUVA}_{254}$ were typical of environments that export large quantities of high molecular-weight, highly aromatic DOM such as some tropical rivers (e.g., Lambert et al., 2016; Mann et al., 2014), streams draining wetlands (e.g., Ågren et al., 2008; Austnes et al., 2010), or streams draining small undisturbed catchments comprised of mixed forest and wetlands (e.g., Wickland et al., 2007; Fellman et al., 2009a; Spencer et al., 2010; Yamashita et al., 2011). This suggests that the majority of the DOM pool is comprised of larger molecules that have not been extensively chemically or biologically degraded through processes such as microbial utilization or photodegradation and therefore are potentially more biologically available (Amon and Benner, 1996).

Biological utilization of DOM is influenced by its composition (e.g., Judd et al., 2006; Fasching et al., 2014); therefore, differences in DOM can alter the downstream fate and ecological role of freshwater-exported DOM. For example, the majority of the fluorescent DOM pool was comprised of $\mathrm{C} 1$, which is described as humic-like, less processed terrestrial soil and plant material (see Table 2). In addition, although the tryptophan-like component $\mathrm{C} 6$, represents a minor proportion of total fluorescence, even a small proteinaceous fraction of the overall DOM pool can play a major role in overall bioavailability and bacterial utilization of DOM (Berggren et al., 2010; Guillamette and Giorgio, 2011). These contributions of stream-exported DOM may represent a relatively fresh, seasonally consistent contribution of terrestrial subsidy from streams to the coastal ecosystem, which in this region is relatively lower in carbon and nutrients throughout much of the year (Whitney et al., 2005; Johannessen et al., 2008).

\subsection{DOC and DOM export: sources and seasonal variability}

On Calvert and Hecate islands, the relationship between DOC concentration and discharge varied by watershed (see Supplement Fig. S6.1), as might be expected given the known influence of watershed characteristics (e.g., lake area, wetland area, soils, etc.) on DOC concentration and export. However, overall DOC concentrations increased in all watersheds with both discharge and temperature indicating that the overarching drivers of DOC export are the hydrologic coupling of precipitation and runoff from the landscape with the seasonal production and availability of DOC (Fasching et al., 2016).

Precipitation is a well-established driver of stream DOC export (Alvarez-Cobelas et al., 2012), particularly in systems containing organic soils and wetlands (Olefeldt et al., 2013; Wallin et al., 2015; Leach et al., 2016). Frequent, high-intensity precipitation events and short residence times are expected to result in pulsed exports of stream DOC that are rapidly shunted downstream, thus reducing time for instream processing (Raymond et al., 2016). Flashy stream hydrographs indicate that hydrologic response times for Calvert and Hecate island watersheds are rapid, presumably as a result of small catchment size, high drainage density, and relatively shallow soils with high hydraulic conductivity (Gibson et al., 2000; Fitzgerald et al., 2003). Rapid runoff is presumably accompanied by rapid increases in water tables and lateral movement of water through shallow soil layers rich in organic matter (Fellman et al., 2009b; D'Amore et al., 2015b). It appears that on Calvert and Hecate islands, the combination of high rainfall, rapid runoff, and abundant sources of DOC from organic-rich wetlands and forests results in high DOC fluxes.

The relationship between DOC, stream temperature, and discharge indicates that seasonal dynamics play an important role in the variability of DOC exported from these systems. For example, DOC concentrations decrease in all watersheds during the wet period of the year; these decreases are associated with clear changes in DOM composition, such as increasing $\delta^{13} \mathrm{C}$-DOC and $\mathrm{SUVA}_{254}$, and decreasing $S_{\mathrm{R}}$. This is in contrast with patterns observed during the dry period, when DOC concentrations gradually increase, while $\delta^{13} \mathrm{C}$ DOC, SUVA 254 decrease. Fluctuations in DOC and DOM composition occur throughout the wet and the dry season, suggesting that temperature and runoff - and perhaps other seasonal drivers - are important year-round controls on DOC concentration as well as certain measures of DOM composition, such as $\delta^{13} \mathrm{C}$-DOC and $S_{\mathrm{R}}$.

The process of "DOC flushing" has been shown to increase stream water DOC during higher flows in coastal and temperate watersheds (e.g., Sanderman et al., 2009; Deirmendjian et al., 2017). Flushing can occur through various mechanisms. For example, Boyer et al. (1996) observed that during drier periods, DOC pools can increase in soils and are then flushed to streams when water tables rise. Rising water tables can establish strong hydraulic gradients that initiate and sustain prolonged increases in metrics like SUVA 254 , until the progressive drawdown of upland water tables constrains flow paths (Lambert et al., 2013). DOC concentrations can vary during flushing in response to changing flow paths, which can shift sources of DOC within the soil profile from older material in deeper soil horizons to more recently produced material in shallow horizons (Sanderman et al., 2009) or from changes in the production mechanism of DOC (Lambert et al., 2013). For example, Sanderman et al. (2009), observed distinct relationships between discharge 
and both $\delta^{13} \mathrm{C}$-DOC and $\mathrm{SUVA}_{254}$ and postulated that during the rainy season, hillslope flushing shifts DOM sources to more aged soil organic material. In addition, instream production can also provide a source of DOC and therefore affect seasonal variation in DOC concentration and composition (Lambert et al., 2013). The extent of these effects can shift seasonally; relationships between flow paths and DOC export in rain-dominated catchments can vary within and between hydrologic periods depending on factors such as the degree of soil saturation, the duration of previous drying and rewetting cycles, soil chemistry, and DOM source-pool availability (Lambert et al., 2013).

Our observations of changes in DOC and DOM related to discharge and stream temperature suggest that a variety of mechanisms may be important for controlling dynamics of seasonal export in Pacific hypermaritime watersheds. We observed elevated DOC concentrations during precipitation events following extended dry periods, suggesting DOC may accumulate during dry periods and be flushed to streams during runoff events. Increased discharge was significantly related to $\delta^{13} \mathrm{C}$-DOC and $S_{\mathrm{R}}$, with higher discharge resulting in more terrestrial-like DOM. One possible explanation is that hydrologic connectivity increases during higher discharge as soil conditions become more saturated, therefore promoting the mobilization of DOM from across a wider range of the soil profile (McKnight et al., 2001; Kalbitz et al., 2002). In addition, the mechanisms of DOC production and sources of DOC appear to shift seasonally. Relationships between increased temperature and lower values of $\delta^{13} \mathrm{C}$-DOC and higher values of the freshness index, $\mathrm{C} 1$, and $\mathrm{C} 4$ suggest that warmer conditions result in a fresh supply of DOM exported from terrestrial sources (Fellman et al., 2009a; Fasching et al., 2016). This may represent a shift in the source of DOM and/or increased contributions from less aromatic, lower molecular-weight material, such as DOM derived from increased terrestrial primary production (Berggren et al., 2010). Further, fine-scaled investigation into the mechanistic underpinnings of the relationship between discharge, stream temperature, and DOM represents a clear priority for future research in this region.

\subsection{Relationships between watershed attributes and exported DOM}

Previous studies have implicated wetlands as a major driver of DOM composition (e.g., Xenopoulos et al., 2003; Ågren et al., 2008; Creed et al., 2008); however, the analysis of relationships between Calvert and Hecate island landscape attributes and variation in DOM composition suggests that controls on DOM composition are more nuanced than being solely driven by the extent of wetlands. Ågren et al. (2008) found that when wetland area comprised $>10 \%$ of total catchment area, wetland DOM was the most significant driver of stream DOM composition during periods of high hydrologic connectivity. Although wetlands comprise an av- erage of $37 \%$ of our study area, they do not appear to be the single leading driver of variability in DOC concentration and DOM composition. Other factors, such as watershed slope, the depth of organic and mineral soil materials, and the presence of lakes also appear to be influence DOC concentration and DOM composition. The presence of cryptic wetlands (Creed et al., 2003) and limitations of the wetland mapping method could also weaken the link between wetland extent, DOC, and DOM.

In these watersheds, soils with pronounced accumulations of organic matter are not restricted to wetland ecosystems. Peat accumulation in wetland ecosystems results in the formation of organic soils (Hemists), where mobile fractions of DOM accumulate under saturated soil conditions and limited drainage, resulting in the enrichment of poorly biodegradable, more stable humic acids (Stevenson, 1994; Marschner and Kalbitz, 2003). Although Hemist soils comprise $27.8 \%$ of our study area, Folic Histosols, which form under more freely drained conditions, such as steeper slopes, occur over an additional $25.7 \%$ of the area (Supplement S1.2). In freely drained organic soils, high rates of respiration can result in further enrichment of aromatic and more complex molecules, and this material may be rapidly mobilized and exported to streams (Glatzel et al., 2003). This suggests the importance of widely distributed, alternative soil DOM source pools, such as Folic Histosols and associated Podzols with thick forest floors on hillslopes, available to contribute high amounts of terrestrial carbon for export.

Although lakes make up a relatively small proportion of the total landscape area, their influence on DOM export appears to be important. The proportion of lake area can be a good predictor of organic carbon loss from a catchment since lakes often increase hydrologic residence times and thus increase opportunities for biogeochemical processing (Algesten et al., 2004; Tranvik et al., 2009). In our study, watersheds with a larger percentage of lake area exhibited a slower response following rain events (Fig. S2.2) and lower DOC yields, and lake area was correlated with parameters that represent greater autochthonous DOM production or microbial processing such as higher freshness index, $S_{\mathrm{R}}$, and fluorescence index and a higher proportions of component C6. In contrast, watersheds with a high percentage of wetlands contributed DOM that was more allochthonous in composition. Lakes are known to be important landscape predictors of DOC, as increased residence time enables removal via respiration, thus reducing downstream exports from lake outlets (Larson et al., 2007). The proximity of wetlands and lakes to the watershed outlet can also play an important role in the composition of DOM exports (Martin et al., 2006).

\section{Conclusions}

Previous work has demonstrated that freshwater discharge is substantial along the coastal margin of the North Pacific 
temperate rainforest and plays an important role in processes such as ocean circulation (Royer, 1982; Eaton and Moore, 2010). Our finding that small catchments in this region contribute high yields of terrestrial DOC to coastal waters suggests that freshwater inputs may also influence ocean biogeochemistry and food web processes through terrestrial organic-matter subsidies. Our findings also suggest that this region may be currently underrepresented in terms of its role in global carbon cycling. Currently, there is no region-wide carbon flux model for the Pacific coastal temperate rainforest or the greater Gulf of Alaska, which would quantify the importance of this region within the global carbon budget. Our estimates point to the importance of the hypermaritime outercoast zone of the CTR, where subdued terrain, high rainfall, ocean-moderated temperatures and poor bedrock have generated a distinctive bog-forest landscape mosaic within the greater temperate rainforest (Banner et al., 2005). However, even within our geographically limited study area, we observed a range of DOC yields across watersheds. To quantify regional-scale fluxes of rainforest carbon to the coastal ocean, further research will be needed to estimate DOC yields across complex spatial gradients of topography, climate, hydrology, soils, and vegetation. Long-term changes in DOC flux have been observed in many places (e.g., Worrall et al., 2004; Borken et al., 2011; Lepistö et al., 2014; Tank et al., 2016), and continued monitoring of this system will allow us to better understand the underlying drivers of export and evaluate future patterns in DOC yields. Coupled with current studies investigating the fate of terrestrial material in ocean food webs, this work will improve our understanding of coastal carbon patterns and increase capacity for predictions regarding the ecological impacts of climate change.

Data availability. Chemistry and DOC flux data are available in Oliver et al. (2017) (https://doi.org/10.21966/1.321324). Ecosystem comparison plot data are available in Giesbrecht et al. (2015) (https://doi.org/10.21966/1.56481). Stage and discharge time series data are available in Floyd et al. (2016) (https://doi.org/10.21966/1.243102). Lidar-derived watersheds and associated metrics data are available in Gonzalez Arriola et al. (2015) (https://doi.org/10.21966/1.15311).

\section{The Supplement related to this article is available online at https://doi.org/10.5194/bg-14-3743-2017-supplement.}

Author contributions. AAO prepared the paper with contributions from all authors, designed analysis protocols, analyzed samples and performed the modelling and analysis for dissolved organic carbon fluxes, parallel factor analysis of dissolved organic-matter composition, and all remaining statistical analyses. SET assisted with designing the study and overseeing laboratory analyses, crafting the scope of the paper, and determining the analytical approach. IG led the initial DOC sampling design, helped coordinate the research team, oversaw routine sampling and data management, and led the watershed characterization. MCK developed the rating curves and conducted the statistical analysis of discharge measurement uncertainties and rating curve uncertainties. WCF led the hydrology component of this project, selected site locations, installed and designed the hydrometric stations, and developed the rating curves and final discharge calculations. CB and PS collected and analyzed soil field data and prepared the digital soils map of the watersheds. KPL conceived of and co-led the overall study of which this paper is a component, helped assemble and guide the team of researchers who carried out this work and provided input to each stage of the study.

Competing interests. The authors declare that they have no conflict of interest.

Acknowledgements. This work was funded by the Tula Foundation and the Hakai Institute. The authors would like to thank many individuals for their support, including Skye McEwan, Bryn Fedje, Lawren McNab, Nelson Roberts, Adam Turner, Emma Myers, David Norwell, and Chris Coxson for sample collection and data management, Clive Dawson and North Road Analytical for sample processing and data management, Keith Holmes for creating our maps, Matt Foster for database development and support, Shawn Hateley for sensor network maintenance, Jason Jackson, Colby Owen, James McPhail, and the entire staff at Hakai Energy Solutions for installing and maintaining the sensors and telemetry network, and Stewart Butler and Will McInnes for field support. Thanks to Santiago Gonzalez Arriola for generating the watershed summaries and associated data products and Ray Brunsting for overseeing the design and implementation of the sensor network and the data management system at Hakai. Additional thanks to Lori Johnson and Amelia Galuska for soil mapping field assistance, and Francois Guillamette for PARAFAC consultation. Thanks to Dave D'Amore for inspiring the Hakai project to investigate aquatic fluxes at the coastal margin and for technical guidance. Lastly, thanks to Eric Peterson and Christina Munck, who provided significant guidance throughout the process of designing and implementing this study.

Edited by: Steven Bouillon

Reviewed by: three anonymous referees

\section{References}

Ågren, A., Buffam, I., Jansson, M., and Laudon, H.: Importance of seasonality and small streams for the landscape regulation of dissolved organic carbon export, J. Geophys. Res.-Biogeosci., 112, https://doi.org/10.1029/2006JG000381, 2007.

Ågren, A., Buffam, I., Berggren, M., Bishop, K., Jansson, M., and Laudon, H.: Dissolved organic carbon characteristics in boreal streams in a forest-wetland gradient during the transition between winter and summer, J. Geophys. Res.-Biogeosci., 113, https://doi.org/10.1029/2007JG000674, 2008. 
Akaike, H.: Likelihood of a model and information criteria, J. Econometrics, 16, 3-14, https://doi.org/10.1016/03044076(81)90071-3, 1981.

Aitkenhead, J. A. and McDowell, W. H.: Soil C:N ratio as a predictor of annual riverine DOC flux at local and global scales, Global Biogeochem. Cy., 14, 127-138, https://doi.org/10.1029/1999GB900083, 2000.

Alaback, P. B.: Biodiversity patterns in relation to climate: The coastal temperate rainforests of North America, Ecol. Stud., 116, 105-133, https://doi.org/10.1007/978-1-4612-3970-3_7, 1996.

Algesten, G., Sobek, S., Bergström, A., Ågren, A., Tranvik, L., and Jansson, M.: Role of lakes for organic carbon cycling in the boreal zone, Glob. Change Biol., 10, 141-147, https://doi.org/10.1111/j.1365-2486.2003.00721.x, 2004.

Alvarez-Cobelas, M., Angeler, D., Sánchez-Carrillo, S., and Almendros, G.: A worldwide view of organic carbon export from catchments, Biogeochemistry, 107, 275-293, https://doi.org/10.1007/s10533-010-9553-z, 2012.

Amon, R. M. W. and Benner, R.: Bacterial utilization of different size classes of dissolved organic matter, Limnol. Oceanogr., 41, 41-51, 1996.

Aufdenkampe, A., Mayorga, E., Raymond, P., Melack, J., Doney, S., Alin, S., Aalto, R., and Yoo, K.: Riverine coupling of biogeochemical cycles between land, oceans, and atmosphere, Front. Ecol. Environ., 9, 53-60, https://doi.org/10.1890/100014, 2011.

Austnes, K., Evans, C. D., Eliot-Laize, C., Naden, P. S., and Old, G. H.: Effects of storm events on mobilisation and in-stream processing of dissolved organic matter (DOM) in a Welsh peatland catchment, Biogeochemical, 99, 157-173, https://doi.org/10.1007/s10533-009-9399-4, 2010.

Banner, A., LePage, P., Moran, J., and de Groot, A. (Eds.): The HyP3 Project: pattern, process, and productivity in hypermaritime forests of coastal British Columbia - a synthesis of 7year results, Special Report 10, Res. Br., British Columbia Ministry Forests, Victoria, British Columbia, 142 pp., available at: http://www.for.gov.bc.ca/hfd/pubs/Docs/Srs/Srs10.htm (last access: 11 August 2017), 2005.

Battin, T. J., Kaplan, L. A., Findlay, S., Hopkinson, C. S., Marti, E., Packman, A. I., Newbold, D., and Sabater, F.: Biophysical controls on organic carbon fluxes in fluvial networks, Nat. Geosci., 1, 95-100, 2008.

Bauer, J. E., Cai, W. J., Raymond, P. A., T. S., Bianchi, Hopkinson, C. S., and Regnier, P. A. G.: The changing carbon cycle of the coastal ocean, Nature, 504, 61-70, https://doi.org/10.1038/nature12857, 2013.

Berggren, M., Laudon, H., Haei, M., Ström, L., and Jansson, M.: Efficient aquatic bacterial metabolism of dissolved low-molecularweight compounds from terrestrial sources, ISME J., 4, 408-416, https://doi.org/10.1038/ismej.2009.120, 2010.

Boehme, J. and Coble, P.: Characterization of Colored Dissolved Organic Matter Using High-Energy Laser Fragmentation, Environ. Sci. Technol., 34, 3283-3290, https://doi.org/10.1021/es9911263, 2000.

Borken, W., Ahrens, B., Schultz, C., and Zimmermann, L.: Site-tosite variability and temporal trends of DOC concentrations and fluxes in temperate forest soils, Glob. Change Biol., 17: 24282443, https://doi.org/10.1111/j.1365-2486.2011.02390.x, 2011.

Borges, A. V., Darchambeau, F., Teodoru, C. R., Marwick, T. R., Tamooh, F., Geeraert, N., Omengo, F. O., Guérin, F., Lambert,
T., Morana, C., Okuku, E., and Bouillon, S.: Globally significant greenhouse-gas emissions form African inland waters, Nat. Geosci., 8, 637-642, https://doi.org/10.1038/ngeo2486, 2015.

Boyer, E. W., Hornberger, G. M., Bencala, K. E., and McKnight, D.: Overview of a simple model describing variation of dissolved organic carbon in an upland catchment, Ecol. Modell., 86, 183188, 1996.

Burnham, K. P. and Anderson, D. R.: Model selection and multimodel inference, 2nd Edn., Springer, New York, 2002.

Carmack, E., Winsor, P., and William, W.: The contiguous panarctic Riverine Coastal Domain: A unifying concept, Prog. Oceanogr., 139, 13-23, https://doi.org/10.1016/j.pocean.2015.07.014, 2015.

Castillo, M. M., Allan, J. D., Sinsabaugh, R. L., and Kling, G. W.: Seasonal and interannual variation of bacterial production in lowland rivers of the Orinoco basin, Freshwater Biol., 49, 14001414, https://doi.org/10.1111/j.1365-2427.2004.01277.x, 2004.

Clark, J. M., Lane, S. N., Chapman, P. J., and Adamson, J. K.: Export of dissolved organic carbon from an upland peatland during storm events: Implications for flux estimates, J. Hydrol., 347, 438-447, https://doi.org/10.1016/j.jhydrol.2007.09.030, 2007.

Coble, P., Castillo, C., and Avril, B.: Distribution and optical properties of CDOM in the Arabian Sea during the 1995 Southwest Monsoon, Deep-Sea Res. Pt. II, 45, 2195-2223, https://doi.org/10.1016/S0967-0645(98)00068-X, 1998.

Cole, J., Prairie, Y., Caraco, N., McDowell, W., Tranvik, L., Striegl, R., Duarte, C., Kortelainen, P., Downing, J., Middelburg, J., and Melack, J.: Plumbing the Global Carbon Cycle: Integrating Inland Waters into the Terrestrial Carbon Budget, Ecosystems, 10, 172-185, https://doi.org/10.1007/s10021-006-9013-8, 2007.

Cory, R. M. and McKnight, D. M.: Fluorescence spectroscopy reveals ubiquitous presence of oxidized and reduced quinines in dissolved organic matter, Environ. Sci. Technol., 39, 8142-8149, https://doi.org/10.1021/es0506962, 2005.

Creed, I. F., Beall, F. D., Clair, T. A., Dillon, P. J., and Hesslein, R. H.: Predicting export of dissolved organic carbon from forested catchments in glaciated landscapes with shallow soils, Glob. Biogeochem. Cy., 22, GB4024, https://doi.org/10.1029/2008GB003294, 2008.

Creed, I. F., Sanford, S. E., Beall, F. D., Molot, L. A., and Dillon, P. J.: Cryptic wetlands: integrating hidden wetlands in regression models of the export of dissolved organic carbon from forested landscapes, Hydrol. Process., 17, 3629-3648, 2003.

D'Amore, D. V., Edwards, R. T., and Biles, F. E.: Biophysical controls on dissolved organic carbon concentrations of Alaskan coastal temperate rainforest streams, Aquat. Sci., 2, 381-393, https://doi.org/10.1007/s00027-015-0441-4, 2015a.

D'Amore, D. V., Edwards, R. T., Herendeen, P. A., Hood, E., and Fellman, J. B.: Dissolved organic carbon fluxes from hydropedologic units in Alaskan coastal temperate rainforest watersheds, Soil Sci. Soc. Am. J., 79, 378-388, https://doi.org/10.2136/sssaj2014.09.0380, 2015 b.

D’Amore, D. V., Biles, F. E., Nay, M., and Rupp, T. S.: Watershed carbon budgets in the southeastern Alaskan coastal forest region, in: Baseline and projected future carbon storage and greenhousegas fluxes in ecosystems of Alaska, US Geological Survey Professional Paper, 1826, 196 pp., 2016.

Dai, M., Yin, Z., Meng, F., Liu, Q., and Cai, W.J.: Spatial distribution of riverine DOC inputs to the ocean: an 
updated global synthesis, Curr. Opin. Sust., 4, 170-178, https://doi.org/10.1016/j.cosust.2012.03.003, 2012.

Deirmendjian, L., Loustau, D., Augusto, L., Lafont, S., Chipeaux, C., Poirier, D., and Abril, G.: Hydrological and ecological controls on dissolved carbon concentrations in groundwater and carbon export to surface waters in a temperate pine forest watershed, Biogeosciences Discuss., https://doi.org/10.5194/bg-2017-90, in review, 2017.

DellaSala, D. A.: Temperate and Boreal Rainforests of the World, Island Press, Washington, DC, 2011.

Emili, L. and Price, J.: Biogeochemical processes in the soilgroundwater system of a forest-peatland complex, north coast British Columbia, Canada, Northwest Sci., 88, 326-348, https://doi.org/10.3955/046.087.0406, 2013.

Fasching, C., Behounek, B., Singer, G., and Battin, T.: Microbial degradation of terrigenous dissolved organic matter and potential consequences for carbon cycling in brown-water streams, Sci. Rep., 4, 4981, https://doi.org/10.1038/srep04981, 2014.

Fasching, C., Ulseth, A., Schelker, J., Steniczka, G., and Battin, T.: Hydrology controls dissolved organic matter export and composition in an Alpine stream and its hyporheic zone, Limnol. Oceanogr., 61, 558-571, https://doi.org/10.1002/lno.10232, 2016.

Fellman, J., Hood, E., D'Amore, D., Edwards, R., and White, D.: Seasonal changes in the chemical quality and biodegradability of dissolved organic matter exported from soils to streams in coastal temperate rainforest watersheds, Biogeochemistry, 95, 277-293, https://doi.org/10.1007/s10533-009-9336-6, 2009a.

Fellman, J., Hood, E., Edwards, R., and D'Amore, D.: Changes in the concentration, biodegradability, and fluorescent properties of dissolved organic matter during stormflows in coastal temperate watersheds, J. Geophys. Res.-Biogeo., 114, https://doi.org/10.1029/2008JG000790, 2009b.

Fellman, J., Hood, E., and Spencer, R.: Fluorescence spectroscopy opens new windows into dissolved organic matter dynamics in freshwater ecosystems: A review, Limnol. Oceanogr., 55, 24522462, https://doi.org/10.4319/lo.2010.55.6.2452, 2010.

Fellman, J., Nagorski, S., Pyare, S., Vermilyea, A. W., Scott, D., and Hood, E.: Stream temperature response to variable glacier cover in coastal watersheds of Southeast Alaska, Hydrol. Process., 28, 2062-2073, https://doi.org/10.1002/hyp.9742, 2014

Finlay, J. C. and Kendall, C.: Stable isotope tracing of temporal and spatial variability in organic matter sources and variability in organic matter sources to freshwater ecosytems, in: Stable Isotopes in Ecology and Environmental Science, edited by: Michener, R. and Lajtha, K., Blackwell Publishing Ltd, Oxford, UK, 2, 283 324, 2007

Fitzgerald, D., Price, J., and Gibson, J.: Hillslope-swamp interactions and flow pathways in a hypermaritime rainforest, British Columbia, Hydrol. Process., 17, 3005-3022, https://doi.org/10.1002/hyp.1279, 2003.

Gibson, J. J., Price, J. S., Aravena, R., Fitzgerald, D. F., and Maloney, D.: Runoff generation in a hypermaritime bog-forest upland, Hydrol. Process, 14 , 2711-2730, https://doi.org/10.1002/10991085(20001030)14:15<2711::AID-HYP88>3.0.CO;2-2, 2000.

Glatzel, S., Kalbitz, K., Dalva, M., and Moore, T.: Dissolved organic matter properties and their relationship to carbon dioxide efflux from restored peat bogs, Geoderma, 113, 397-411, 2003.
Gonzalez Arriola S., Frazer, G. W., and Giesbrecht, I.: LiDARderived watersheds and their metrics for Calvert Island, Hakai Institute, https://doi.org/10.21966/1.15311, 2015.

Gorham, E., Lehman, C., Dyke, A., Clymo, D., and Janssens, J.: Long-term carbon sequestration in North American peatlands, Quaternary Sci. Rev., 58, 77-82, 2012.

Graeber, D., Gelbrecht, J., Pusch, M., Anlanger, C., and von Schiller, D.: Agriculture has changed the amount and composition of dissolved organic matter in Central European headwater streams, Sci. Total Environ., 438, 435-446, https://doi.org/10.1016/j.scitotenv.2012.08.087, 2012.

Green, R. N.: Reconnaissance level terrestrial ecosystem mapping of priority landscape units of the coast EBM planning area: Phase 3, Prepared for British Columbia Ministry Forests, Lands and Natural Resource Ops., Blackwell and Associates, Vancouver, Canada, 2014.

Guillemette, F. and Giorgio, P.: Reconstructing the various facets of dissolved organic carbon bioavailability in freshwater ecosystems, Limnol. Oceanogr., 56, 734-748, https://doi.org/10.4319/lo.2011.56.2.0734, 2011.

Hansen, A. M., Kraus, T. E. C., Pellerin, B. A., Fleck, J. A., Downing, B. D., and Bergamaschi, B. A.: Optical properties of dissolved organic matter (DOM): Effects of biological and photolytic degradation, Limnol. Oceanogr., 61, 1015-1032, https://doi.org/10.1002/lno.10270, 2016.

Harrell, F. E. and Dupont, C.: Hmisc: Harrell Miscellaneous. $\mathrm{R}$ package version 4.0-2. https://CRAN.R-project.org/package= Hmisc, 2016.

Harrison, J., Caraco, N., and Seitzinger, S.: Global patterns and sources of dissolved organic matter export to the coastal zone: Results from a spatially explicit, global model, Global Biogeochem. Cy., 19, https://doi.org/10.1029/2005gb002480, 2005.

Helms, J., Stubbins, A., Ritchie, J., Minor, E., Kieber, D., and Mopper, K.: Absorption spectral slopes and slope ratios as indicators of molecular weight, source, and photobleaching of chromophoric dissolved organic matter, Limnol. Oceanogr., 53, 955969, https://doi.org/10.4319/lo.2008.53.3.0955, 2008.

Helton, A., Wright, M., Bernhardt, E., Poole, G., Cory, R., and Stanford, J.: Dissolved organic carbon lability increases with water residence time in the alluvial aquifer of a river floodplain ecosystem, J. Geophys. Res.-Biogeo., 120, 693-706, https://doi.org/10.1002/2014JG002832, 2015.

Hoffman, K. M., Gavin, D. G., Lertzman, K. P., Smith, D. J., and Starzomski, B. M.: 13000 years of fire history derived from soil charcoal in a British Columbia coastal temperate rain forest, Ecosphere, 7, e01415, https://doi.org/10.1002/ecs2.1415, 2016.

Hope, D., Billett, M. F., and Cresser, M. S.: A review of the export of carbon in river water: Fluxes and processes, Environ. Pollut., 84, 301-324, https://doi.org/10.1016/0269-7491(94)90142-2, 1994.

Hopkinson, C. S., Buffam, I., Hobbie, J., Vallino, J., and Perdue, M.: Terrestrial inputs of organic matter to coastal ecosystems: An intercomparison of chemical characteristics and bioavailability, Biogeochemistry, 43, 211-234, 1998.

Hudson, N., Baker, A., and Reynolds, D.: Fluorescence analysis of dissolved organic matter in natural, waste and polluted waters-a review, River Res. Appl., 23, 631-649, https://doi.org/10.1002/rra.1005, 2007. 
Hurvich, C. M. and Tsai, C.: Regression and time series model selection in small samples, Biometrika, 76, 297-307, https://doi.org/10.2307/2336663, 1989.

IUSS Working Group WRB: World Reference Base for Soil Resources, International soil classification system for naming soils and creating legends for soil maps, World Soil Resources Reports No. 106, Food and Agricultural Organization of the United Nations, Rome, Italy, 2015.

ISO Standard 9196: Liquid flow measurement in open channels Flow measurements under ice conditions, International Organization for Standardization, available online at: www.iso.org (last access: 1 November 2016), 1992.

ISO Standard 748: Hydrometry - Measurement of liquid flow in open channels using current-meters or floats, International Organization for Standardization, available online at: www.iso.org (last access: 1 November 2016), 2007.

Johannessen, S. C., Potentier, G., Wright, C. A., Masson, D., and Macdonald, R. W.: Water column organic carbon in a Pacific marginal sea (Strait of Georgia, Canada), Mar. Environ. Res., 66, S49-S61, https://doi.org/10.1016/j.marenvres.2008.07.008, 2008.

Johnson, M., Couto, E., Abdo, M., and Lehmann, J.: Fluorescence index as an indicator of dissolved organic carbon quality in hydrologic flowpaths of forested tropical watersheds, Biogeochemistry, 105, 149-157, https://doi.org/10.1007/s10533-011-9595-x, 2011.

Johnson, P. C. D.: Extension of Nakagawa and Schielzeth's $R_{\text {GLMM }}^{2}$ to random slopes models, Methods Ecol. Evol., 5, 944-946, https://doi.org/10.1111/2041-210X.12225, 2014.

Judd, K., Crump, B., and Kling, G.: Variation in dissolved organic matter controls bacterial production and community composition, Ecology, 87, 2068-2079, https://doi.org/10.1890/00129658(2006)87[2068:VIDOMC]2.0.CO;2, 2006.

Kalbitz, K., Schmerwitz, J., Schwesig, D., and Matzner, E.: Biodegradation of soil-derived dissolved organic matter as related to its properties, Geoderma, 113, 273-291, https://doi.org/10.1016/S0016-7061(02)00365-8, 2003.

Kling, G., Kipphut, G., Miller, M., and O'Brien, W.: Integration of lakes and streams in a landscape perspective: the importance of material processing on spatial patterns and temporal coherence, Freshwater Biol., 43, 477-497, https://doi.org/10.1046/j.13652427.2000.00515.x, 2000.

Koehler, A.-K., Murphy, K., Kiely, G., and Sottocornola, M.: Seasonal variation of DOC concentration and annual loss of DOC from an Atlantic blanket bog in South Western Ireland, Biogeochemistry, 95, 231-242, https://doi.org/10.1007/s10533-0099333-9, 2009.

Lakowicz, J. R.: Principles of Fluorescence Spectroscopy, 2, Kluwer Academic, New York, 1999.

Larson, J. H., Frost, P. C., Zheng, Z., Johnston, C. A., Bridgham, S. D., Lodge, D. M., and Lamberti, G. A.: Effects of upstream lakes on dissolved organic matter in streams, Limnol. Oceanogr., 52, 60-69, https://doi.org/10.4319/lo.2007.52.1.0060, 2007.

Leighty, W. W., Hamburg, S. P., and Caouette, J.: Effects of management on carbon sequestration in forest biomass in Southeast Alaska, Ecosystems, 9, 1051, https://doi.org/10.1007/s10021005-0028-3, 2006.
Lalonde, K., Middlestead, P., Gélinas, Y.: Automation of 13C/12C ratio measurement for freshwater and seawater DOC using high temperature combustion, Limnol. Oceanogr.-Meth., 12, 816829, https://doi.org/10.4319/lom.2014.12.816, 2014.

Lambert, T., Bouillon, S., Darchambeau, F., Massicotte, P., and Borges, A. V.: Shift in the chemical composition of dissolved organic matter in the Congo River network, Biogeosciences, 13, 5405-5420, https://doi.org/10.5194/bg-13-5405-2016, 2016.

Leach, J., Larsson, A., Wallin, M., Nilsson, M., and Laudon, H.: Twelve year interannual and seasonal variability of stream carbon export from a boreal peatland catchment, J. Geophys. Res. 121, 1851-1866, https://doi.org/10.1002/2016JG003357, 2016.

Legendre, P. and Durand, S.: rdaTest, Canonical redundancy analysis, $\mathrm{R}$ package version 1.11, available at: http://adn.biol. umontreal.ca/ numericalecology/Rcode/ (last access: 1 January 2017), 2014.

Lepistö, A., Futter, M .N., and Kortelainen, P.: Almost 50 years of monitoring shows that climate, not forestry, controls long-term organic carbon fluxes in a large boreal watershed, Glob. Change Biol., 20, 1225-1237, https://doi.org/10.1111/gcb.12491, 2014.

Liaw, A. and Wiener, M.: Classification and Regression by randomForest, R News, 2, 18-22, 2002.

Lochmuller, C. H. and Saavedra, S. S.: Conformational changes in a soil fulvic acid measured by time dependent fluorescence depolarization, Anal. Chem., 38, 1978-1981, 1986.

Lorenz, D., Runkel, R., and De Cicco, L.: rloadest, River Load Estimation, $\mathrm{R}$ package version 0.4 .2 , available at: https://github.com/ USGS-R/rloadest, 2015.

Ludwig, W., Probst, J., and Kempe, S.: Predicting the oceanic input of organic carbon by continental erosion, Global Biogeochem. Cy., 10, 23-41, https://doi.org/10.1029/95GB02925, 1996.

Mann, P. J., Spencer, R. G. M., Dinga, B. J., Poulsen, J. R., Hernes, P. J., Fiske, G., Salter, M. E., Wang, Z. A., Hoering, K. A., Six, J., and Holmes, R. M.: The biogeochemistry of carbon across a gradient of sreams and rivers within the Congo Basin, J. Geophys. Res.-Biogeo., 119, 687-702, https://doi.org/10.1002/2013JG002442, 2014.

Marschner, B. and Kalbitz, K.: Controls on bioavailability and biodegradability of dissolved organic matter in soils, Geoderma, 113, 211-235, 2003.

Martin, S. L. and Soranno, P. A.: Lake landscape position: Relationships to hydrologic connectivity and landscape features, Limnol. Oceanogr., 51, 801-814, https://doi.org/10.4319/lo.2006.51.2.0801, 2006.

Masiello, C. A. and Druffel, E. R. M.: Carbon isotope geochemistry of the Santa Clara River, Global Biogeochem. Cy., 15, 407-416, https://doi.org/10.1029/2000GB001290, 2001.

Mayorga, E., Seitzinger, S., Harrison, J., Dumont, E., Beusen, A., Bouwman, A. F., Fekete, B., Kroeze, C., and Drecht, G.: Global Nutrient Export from WaterSheds 2 (NEWS 2): Model development and implementation, Environ. Model. Softw., 25, 837-853, https://doi.org/10.1016/j.envsoft.2010.01.007, 2010.

McClelland, J., Townsend-Small, A., Holmes, R., Pan, F., Stieglitz, M., Khosh, M., and Peterson, B.: River export of nutrients and organic matter from the North Slope of Alaska to the Beaufort Sea, Water Resour. Res., 50, 1823-1839, https://doi.org/10.1002/2013WR014722, 2014.

McKnight, D., Boyer, E., Westerhoff, P., Doran, P., Kulbe, T., and Andersen, D.: Spectrofluorometric characterization 
of dissolved organic matter for indication of precursor organic material and aromaticity, Limnol. Oceanogr., 46, 38-48, https://doi.org/10.4319/1o.2001.46.1.0038, 2001.

McLaren, D., Fedje, D., Hay, M. B., Mackie, Q., Walker, I. J., Shugar, D. H., Eamer, J. B. R., Lian, O. B., and Neudorf, C.: A post-glacial sea level hinge on the central Pacific coast of Canada, Quaternary Sci. Rev.., 97, 148-169, 2014.

Meybeck, M.: Carbon, nitrogen, and phosphorus transport by world rivers, Am. J. Sci., 282, 401-450, available from: http:// earth.geology.yale.edu/ ajs/1982/04.1982.01.Maybeck.pdf (last access: 11 August 2017), 1982.

Milliman, J. D. and Syvitski J. P. M.: Geomorphic tectonic control of sediment discharge to the ocean: The importance of small mountainous rivers, J. Geol., 100, 525-544, 1992.

Moore, R. D.: Introduction to salt dilution gauging for streamflow measurement part III: Slug injection using salt in solution, Streamline Watershed Management Bulletin, 8, 1-6, 2005.

Morrison, J., Foreman, M. G. G., and Masson, D.: A method for estimating monthly freshwater discharge affecting British Columbia coastal waters, Atmos.-Ocean, 50, 1-8, https://doi.org/10.1080/07055900.2011.637667, 2012.

Mulholland, P. and Watts, J.: Transport of organic carbon to the oceans by rivers of North America: a synthesis of existing data, Tellus, 34, 176-186, https://doi.org/10.1111/j.21533490.1982.tb01805.x, 1982.

Murphy, K., Stedmon, C., Graeber, D., and Bro, R.: Fluorescence spectroscopy and multi-way techniques. PARAFAC, Anal. Methods, 5, 6557-6566, https://doi.org/10.1039/C3AY41160E, 2013.

Murphy, K., Stedmon, C., Wenig, P., and Bro, R.: OpenFluor - A spectral database of auto-fluorescence by organic compounds in the environment, Anal. Methods, 6, 658-661, https://doi.org/10.1039/C3AY41935E, 2014.

Naiman, R. J.: Characteristics of sediment and organic carbon export from pristine boreal forest watersheds, Can. J. Fish. Aquat. Sci., 39, 1699-1718, https://doi.org/10.1139/f82-226, 1982.

Nakagawa, S. and Schielzeth, H.: A general and simple method for obtaining $R^{2}$ from generalized linear mixed-effects models, Methods Ecol. Evol., 4, 133-142, https://doi.org/10.1111/j.2041210x.2012.00261.x, 2013.

Olefeldt, D., Roulet, N., Giesler, R., and Persson, A.: Total waterborne carbon export and DOC composition from ten nested subarctic peatland catchments-importance of peatland cover, groundwater influence, and inter-annual variability of precipitation patterns, Hydrol. Process., 27, 2280-2294, https://doi.org/10.1002/hyp.9358, 2013.

Oliver, A. A., Tank, S. E. , Giesbrecht, I., Korver, M. C., Floyd, W. C., Sanborn, P., Bulmer, C., and Lertzman, K. P.: Aquatic carbon flux data package, https://doi.org/10.21966/1.321324, 2017

Pinheiro, J., Bates, D., DebRoy, S., Sarkar, D., and R Core Team: nlme: Linear and Nonlinear Mixed Effects Models, R package version 3.1-128, 2016.

Pojar, J., Klinka, K., and Demarchi, D. A.: Chapter 6, Coastal Western Hemlock Zone, in: Special Report Series 6, Ecosystems of British Columbia, edited by: Meidiner, D. and Pojar, J., Ministry of Forests, British Columbia, Victoria, 330 pp., 1991.

Poulin, B., Ryan, J., and Aiken, G.: Effects of iron on optical properties of dissolved organic matter, Environ. Sci. Technol., 48, 10098-106, https://doi.org/10.1021/es502670r, 2014.
R Core Team, R: A language and environment for statistical computing, R Foundation for Statistical Computing, Vienna, Austria, http://www.R-project.org/ (last access: 11 August 2017), 2013.

Raymond, P., Saiers, J., and Sobczak, W.: Hydrological and biogeochemical controls on watershed dissolved organic matter transport: pulse-shunt concept, Ecology, 97, 5-16, https://doi.org/10.1890/14-1684.1, 2016.

Regnier, P., Friedlingstein, P., Ciais, P., Mackenzie, F., Gruber, N., Janssens, I., Laruelle, G., Lauerwald, R., Luyssaert, S., Andersson, A., Arndt, S., Arnosti, C., Borges, A., Dale, A., Gallego-Sala, A., Goddéris, Y., Goossens, N., Hartmann, J., Heinze, C., Ilyina, T., Joos, F., LaRowe, D., Leifeld, J., Meysman, F., Munhoven, G., Raymond, P., Spahni, R., Suntharalingam, P., and Thullner, M.: Anthropogenic perturbation of the carbon fluxes from land to ocean, Nat. Geosci., 6, 597-607, https://doi.org/10.1038/ngeo1830, 2013.

Roddick, J. R.: Geology, Rivers Inlet-Queens Sound, British Columbia, Open File 3278, Geological Survey of Canada, Ottawa, Canada, 1996.

Royer, T. C.: Coastal fresh water discharge in the northeast, Pacific, J. Geophys. Res., 87, 2017-2021, 1982.

Runkel, R. L., Crawford, C. G., and Cohn, T. A.: Load Estimator (LOADEST): A FORTRAN program for estimating constituent loads in streams and rivers, U.S. Geological Survey Techniques and Methods Book 4, Chapter A5, 65 pp., 2004.

Sanderman, J., Lohse, K. A., Baldock, J. A., and Amundson, R.: Linking soils and streams: Sources and chemistry of dissolved organic matter in a small coastal watershed, Water Resourc. Res., 45, W03418, https://doi.org/10.1029/2008WR006977, 2009.

Spencer, R., Butler, K., and Aiken, G.: Dissolved organic carbon and chromophoric dissolved organic matter properties of rivers in the USA, J. Geophys. Res.-Biogeo., 117, G03001, https://doi.org/10.1029/2011JG001928, 2012.

Spencer, R. G., Hernes, P. J., Ruf, R., Baker, A., Dyda, R. Y., Stubbins, A., and Six, J.: Temporal controls on dissolved organic matter and lignin biogeochemistry in a pristine tropical river, Democratic Republic of Congo, J. Geophys. Res., 115, G03013, https://doi.org/10.1029/2009JG001180, 2010.

Stackpoole, S. M., Butman, D. E., Clow, D. W., Verdin, K. L., Gaglioti, B., and Striegl, R.: Carbon burial, transport, and emission from inland aquatic ecosystems in Alaska, in: Baseline and projected future carbon storage and greenhouse-gas fluxes in ecosystems of Alaska, edited by: Zhiliang, Z., and David, A., US Geological Survey Professional Paper, 1826, 196 pp., 2016.

Stackpoole, S. M., Butman, D. E., Clow, D. W., Verdin, K. L., Gaglioti, B. V., Genet, H., and Striegl, R. G.: Inland waters and their role in the carbon cycle of Alaska, Ecol. Appl., 27, 14031420, https://doi.org/10.1002/eap.1552, 2017.

Stedmon, C. and Bro, R.: Characterizing dissolved organic matter fluorescence with parallel factor analysis: a tutorial, Limnol. Oceanogr.-Meth., 6, 572-579, https://doi.org/10.4319/lom.2008.6.572b, 2008.

Stedmon, C. and Markager, S.: Tracing the production and degradation of autochthonous fractions of dissolved organic matter by fluorescence analysis, Limnol. Oceanogr., 50, 1415-1426, https://doi.org/10.4319/lo.2005.50.5.1415, 2005.

Stedmon, C., Markager, S., Bro, R., Stedmon, C., Markager, S., and Bro, R.: Tracing dissolved organic matter in aquatic environments using a new approach to fluorescence spectroscopy, 
Mar. Chem., 82, 239-254, https://doi.org/10.1016/S03044203(03)00072-0, 2003.

Stevenson, F. J.: Humus Chemistry: Genesis, Composition, Reactions, 2, Jon Wiley and Sons Inc., New York, United States of America, 1994.

Symonds, M. R. E. and Moussalli, A.: A brief guide to model selection, multimodel inference, and model averaging in behavioural ecology using Akaike's information criterion, Behav. Ecol. Sociobiol., 65, 13-21, https://doi.org/10.1007/s00265-010-1037-6, 2011.

Tallis, H.: Kelp and rivers subsidize rocky intertidal communities in the Pacific Northwest (USA), Mar. Ecol.-Prog. Ser., 389, 8596, https://doi.org/10.3354/meps08138, 2009.

Tank, S., Raymond, P., Striegl, R., McClelland, J., Holmes, R., Fiske, G., and Peterson, B.: A land-to-ocean perspective on the magnitude, source and implication of DIC flux from major Arctic rivers to the Arctic Ocean, Global Biogeochem. Cy., 26, GB4018, https://doi.org/10.1029/2011GB004192, 2012.

Tank, S., Striegl, R. G., McClelland, J. W., and Kokelij, S. V.: Multidecadal increases in dissolved organic carbon and alkalinity flux from the Mackenzie drainage basin to the Arctic Ocean, Environ. Res. Lett., 11, https://doi.org/10.1088/1748-9326/11/5/054015, 2016.

Thompson, S. D., Nelson, T. A., Giesbrecht, I., Frazer, G., and Saunders, S. C.: Data-driven regionalization of forested and non-forested ecosystems in coastal British Columbia with LiDAR and RapidEye imagery, Appl. Geogr., 69, 35-50, https://doi.org/10.1016/j.apgeog.2016.02.002, 2016.

Trant, A. J., Niijland, W., Hoffman, K. M., Mathews, D. L., McLaren, D., Nelson, T. A., and Starzomski, B. M.: Intertidal resource use over millennia enhances forest productivity, Nat. Commun., 7, 12491, https://doi.org/10.1038/ncomms12491, 2016.

van Hees, P., Jones, D., Finlay, R., Godbold, D., and Lundström, U.: The carbon we do not see-the impact of low molecular weight compounds on carbon dynamics and respiration in forest soils: a review, Soil Biol. Biochem., 37, 1-13, https://doi.org/10.1016/j.soilbio.2004.06.010, 2005.

Wallin, M., Weyhenmeyer, G., Bastviken, D., Chmiel, H., Peter, S., Sobek, S., and Klemedtsson, L.: Temporal control on concentration, character, and export of dissolved organic carbon in two hemiboreal headwater streams draining contrasting catchments, J. Geophys. Res.-Biogeo., 120, 832-846, https://doi.org/10.1002/2014jg002814, 2015.
Wang, T., Hamann, A., Spittlehouse, D. L., and Murdock, T. Q.: ClimateWNA- High resolution spatial climate data for Western North America, J. Appl. Meterol. Climatol., 51, 16-29, https://doi.org/10.1175/JAMC-D-11-043.1, 2012.

Weishaar, J. L., Aiken, G. R., Bergamaschi, B. A., Fram, M. S., Fujii, R., and Mopper, K.: Evaluation of specific ultraviolet absorbance as an indicator of the chemical composition and reactivity of dissolved organic carbon, Environ. Sci. Technol., 37, 47024708, https://doi.org/10.1021/es030360x, 2003.

Whitney, F. A., Crawford, W. R., and Harrison, P. J.: Physical processes that enhance nutrient transport and primary productivity in the coastal and open ocean of the subarctic NE Pacific, Deep-Sea Res. Pt. II, 52, 681-706, 2005.

Wickland, K., Neff, J., and Aiken, G.: Dissolved Organic Carbon in Alaskan Boreal Forest: Sources, Chemical Characteristics, and Biodegradability, Ecosystems, 10, 1323-1340, 2007.

Wilson, H. F. and Xenopoulos, M. A.: Effects of agricultural land use on the composition of fluvial dissolved organic matter, Nat. Geosci., 2, 37-41, https://doi.org/10.1038/ngeo391, 2009.

Wolf, E. C., Mitchell, A. P., and Schoonmaker, P. K.: The Rain Forests of Home: An Atlas of People and Place, Ecotrust, Pacific GIS, Inforain, and Conservation International, Portland, Oregon, 24 pp., available at: http://www.inforain.org/pdfs/ctrf_atlas_orig. pdf, 1995.

Worrall, F., Burt, T., and Adamson, J.: Can climate change explain increases in DOC flux from upland peat catchements?, Sci. Total. Environ., 326, 95-112, https://doi.org/10.1016/j.scitotenv.2003.11.022, 2004.

Xenopoulos, M. A., Lodge, D. M., Frentress, J., Kreps, T. A., Bridgham, S. D., Grossman, E., and Jackson, C. J.: Regional comparisons of watershed determinants of dissolved organic carbon in temperate lakes from the Upper Great Lakes region and selected regions globally, Limnol. Oceanogr., 48, 2321-2334, 2003.

Yamashita, Y. and Jaffeì, R.: Characterizing the Interactions between Trace Metals and Dissolved Organic Matter Using Excitation-Emission Matrix and Parallel Factor Analysis, Environ. Sci. Technol., 42, 7374-7379, https://doi.org/10.1021/es801357h, 2008.

Yamashita, Y., Kloeppel, B., Knoepp, J., Zausen, G., and Jaffé, R.: Effects of Watershed History on Dissolved Organic Matter Characteristics in Headwater Streams, Ecosystems, 14, 1110-1122, https://doi.org/10.1007/s10021-011-9469-z, 2011. 